\title{
Benthic phosphorus cycling in the Peruvian oxygen minimum zone
}

\author{
Ulrike Lomnitz ${ }^{1}$, Stefan Sommer ${ }^{1}$, Andrew W. Dale ${ }^{1}$, Carolin R. Löscher ${ }^{1}$, Anna Noffke ${ }^{2}$, Klaus Wallmann ${ }^{1}$, and \\ Christian Hensen ${ }^{1}$ \\ ${ }^{1}$ GEOMAR Helmholtz Centre for Ocean Research Kiel, Wischhofstr. 1-3, 24148 Kiel, Germany \\ ${ }^{2}$ Institut für Seenforschung (ISF) der LUBW, Argenweg 50/1, 88085 Langenargen, Germany
}

Correspondence to: Ulrike Lomnitz (ulomnitz@geomar.de)

Received: 15 September 2015 - Published in Biogeosciences Discuss.: 19 October 2015

Revised: 2 February 2016 - Accepted: 4 February 2016 - Published: 4 March 2016

\begin{abstract}
Oxygen minimum zones (OMZs) that impinge on continental margins favor the release of phosphorus $(\mathrm{P})$ from the sediments to the water column, enhancing primary productivity and the maintenance or expansion of low-oxygen waters. A comprehensive field program in the Peruvian OMZ was undertaken to identify the sources of benthic $\mathrm{P}$ at six stations, including the analysis of particles from the water column, surface sediments, and pore fluids, as well as in situ benthic flux measurements. A major fraction of solid-phase $\mathrm{P}$ was bound as particulate inorganic P (PIP) both in the water column and in sediments. Sedimentary PIP increased with depth in the sediment at the expense of particulate organic $\mathrm{P}$ (POP). The ratio of particulate organic carbon (POC) to POP exceeded the Redfield ratio both in the water column $(202 \pm 29)$ and in surface sediments $(303 \pm 77)$. However, the POC to total particulate $\mathrm{P}(\mathrm{TPP}=\mathrm{POP}+\mathrm{PIP})$ ratio was close to Redfield in the water column $(103 \pm 9)$ and in sediment samples $(102 \pm 15)$. This suggests that the relative burial efficiencies of POC and TPP are similar under low-oxygen conditions and that the sediments underlying the anoxic waters on the Peru margin are not depleted in $\mathrm{P}$ compared to Redfield. Benthic fluxes of dissolved $\mathrm{P}$ were extremely high (up to $1.04 \pm 0.31 \mathrm{mmol} \mathrm{m}^{-2} \mathrm{~d}^{-1}$ ), however, showing that a lack of oxygen promotes the intensified release of dissolved $\mathrm{P}$ from sediments, whilst preserving the POC / TPP burial ratio. Benthic dissolved P fluxes were always higher than the TPP rain rate to the seabed, which is proposed to be caused by transient $\mathrm{P}$ release by bacterial mats that had stored $\mathrm{P}$ during previous periods when bottom waters were less reducing. At one station located at the lower rim of the OMZ, dissolved $\mathrm{P}$ was taken up by the sediments, indicating ongoing phosphorite formation. This is further supported by decreasing porewater phosphate concentra-
\end{abstract}

tions with sediment depth, whereas solid-phase P concentrations were comparatively high.

\section{Introduction}

Phosphorus is an essential nutrient; it serves as an energy carrier for all living species and is a limiting macronutrient for marine primary production on geological timescales (Ingall and Jahnke, 1994; Föllmi, 1996; McManus et al., 1997; Filippelli, 2002; Paytan and McLaughlin, 2007; Tsandev et al., 2012; Ruttenberg, 2014). Due to its impact on marine primary production, the oceanic phosphorus inventory modulates the atmospheric $\mathrm{CO}_{2}$ level and Earth's climate (Ganeshram et al., 2002; Wallmann, 2003; Ingall, 2010). Hence, it is crucial to understand feedback mechanisms of the $\mathrm{P}$ cycle to make future predictions.

Particulate and dissolved phosphorus in the ocean originates from terrestrial chemical weathering of the $\mathrm{P}$ containing mineral group of apatite (Filippelli, 2002). Only around $30 \%$ of the $\mathrm{P}$ discharged to the oceans is potentially bioavailable (Compton et al., 2000) as dissolved P, inorganic P adsorbed to minerals, or associated with metal oxides and $\mathrm{P}$ bound within particulate organic matter. However, the largest fraction of the fluvial $\mathrm{P}$ is trapped in estuaries or buried in continental margin sediments and thereby removed from the $\mathrm{P}$ cycle before it reaches the open ocean (Compton et al., 2000). The delivery of $P$ to the sediments in the open ocean is mainly composed of organic and inorganic $\mathrm{P}$ associated with the export of organic detritus and other particles from the photic zone. $\mathrm{P}$ adsorbed to minerals such as $\mathrm{Mn}$ and $\mathrm{Fe}$ (oxyhydr)oxides (Föllmi, 1996; Delaney, 1998; Faul et al., 2005) are further sources, as well as P input from fish debris 
that could be particularly important in productive upwelling regions (Suess, 1981; Schenau and De Lange, 2001; DìazOchoa et al., 2009; Noffke, 2014).

$\mathrm{P}$ cycling is strongly affected by redox-dependent processes. P can be scavenged by Fe (oxyhydr)oxides in oxic sediment and released across the sediment-water interface due to the reduction dissolution of $\mathrm{Fe}$ (oxyhydr)oxides in anoxic sediments (Sundby et al., 1986; Slomp et al., 1998). Furthermore, recent studies showed that sulfur bacteria found in surface sediments of anoxic environments can internally store and release $\mathrm{P}$ under oscillating redox conditions (Ingall and Jahnke, 1997, and references therein). Therefore, these organisms are a key player for the modulation of porewater $\mathrm{P}$ concentrations and benthic $\mathrm{P}$ release to the water column.

Additionally, hypoxic or anoxic conditions favor the precipitation of $\mathrm{P}$ in the form of authigenic carbonate fluorapatite (CFA) (Froelich et al., 1988; Suess and von Huene, 1988; Goldhammer et al., 2010; Ingall, 2010; Schenau and De Lange, 2000). For non-upwelling areas, the required phosphate oversaturation in the porewaters has been attributed to the reductive dissolution of $\mathrm{P}$ bearing $\mathrm{Fe}$ (oxyhydr)oxides (e.g., Ruttenberg and Berner, 1993, Slomp et al., 1996). In contrast, the CFA formation in sediments of the Namibian upwelling area was linked to microbial P release into the porewaters (Schulz and Schulz, 2005).

The resulting feedback on oceanic primary production and atmospheric $\mathrm{O}_{2}$ and $\mathrm{CO}_{2}$ levels triggered by changes in benthic $\mathrm{P}$ sequestration is still unclear. Presently, three opposing views have been raised: (1) intensified phosphate release from the sediments to the water column caused by an expansion of low-oxygen waters (Ingall and Jahnke, 1994; Stramma et al., 2008) could stimulate the primary production in the surface waters (Wallmann, 2003). This, in turn, may lead to a more intensified oxygen demand and a positive feedback with benthic P release (Slomp and Van Cappellen, 2007; Wallmann, 2010; Moffitt et al., 2015). (2) A negative feedback on P release has been postulated based on observations of CFA mineral precipitation found in the present-day oxygen-depleted upwelling areas (Schulz and Schulz, 2005; Arning et al., 2009a, b; Goldhammer et al., 2010; Cosmidis et al., 2013). Being a major sink for bioavailable P (Delaney, 1998; Ingall, 2010), it has been argued that the expansion of OMZs may increase the CFA precipitation in the sediments and thus mitigate the benthic phosphate release (Ganeshram et al., 2002; Goldhammer et al., 2010; Ingall, 2010). (3) A third scenario suggests that the formation of CFA is in balance with enhanced $P$ release from anoxic sediments, implying that the dissolved oceanic P inventory is largely unaffected by oxygen concentrations (Delaney, 1998; Anderson et al., 2001; Roth et al., 2014). These conflicting scenarios show that there is further need to explore the benthic-pelagic $\mathrm{P}$ cycling in oxygen-deficient environments in order to enable improved predictions.

In this study, we explore P cycling in the Peruvian OMZ to identify and quantify $\mathrm{P}$ sources to the sediment and the
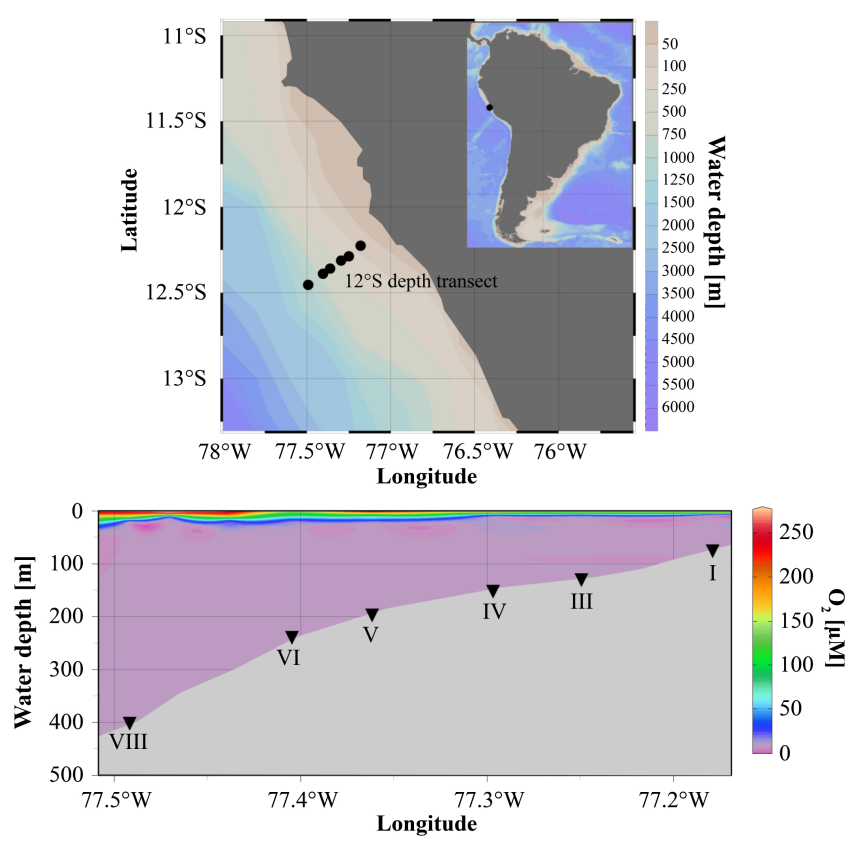

Figure 1. Study area, sampling stations, and $\mathrm{O}_{2}$ concentration in $\mu \mathrm{M}$ along the $12^{\circ} \mathrm{S}$ transect.

return of inorganic dissolved $\mathrm{P}$ back to the water column. Our data set comprises samples of particulate matter from the water column as well as porewater, sediment samples and samples of filamentous sulfur bacteria. We present in situ benthic phosphate fluxes, particulate matter $\mathrm{C} / \mathrm{P}$ ratios for water-column particles and surface sediments and $\mathrm{P}$ burial fluxes, and relative abundances of sulfur bacteria for six stations along the depth transect across the Peruvian shelf at $12^{\circ} \mathrm{S}$. From a mass balance for $\mathrm{P}$ cycling in the sediments, we conclude that the benthic $P$ sources and sinks were, in general, imbalanced during our sampling campaign.

\section{Study area}

The study area is located in the center of the Peruvian OMZ at $12^{\circ} \mathrm{S}$ covering the shallow shelf from $\sim 70 \mathrm{~m}$ water depth to mid-slope depths of about $\sim 400 \mathrm{~m}$ (Fig. 1). During our sampling campaign in January 2013, neutral or slightly negative El Niño-Southern Oscillation (ENSO) conditions dominated (http://www.cpc.ncep.noaa.gov), and the bottom water oxygen concentrations were below the detection limit of the Winkler titration $\left(5 \mu \mathrm{mol} \mathrm{L}{ }^{-1}\right)$ down to $\sim 450 \mathrm{~m}$ water depth (Fig. 1, Table 1). Below the OMZ, oxygen concentrations increased to 19 and $53 \mu \mathrm{M}$ at 770 and $1025 \mathrm{~m}$ water depth, respectively. Nitrate concentrations were below $12 \mu \mathrm{M}$ from 128 to $407 \mathrm{~m}$ water depth (Table 1). During the measuring period, the bottom water at station I (74 m) was sulfidic and depleted in nitrate (Table 1; Sommer et al., 2016).

The oxygen-deficient waters off Peru belong to one of the world's most prominent OMZs. Southeasterly trade winds 
Table 1. Station list for the sites of the benthic lander (BIGO), multi-corer (MUC), and CTD deployments including the bottom water concentrations of oxygen $\left(\mathrm{O}_{2}\right)$, nitrate $\left(\mathrm{NO}_{3}^{-}\right)$, and sulfide $\left(\mathrm{H}_{2} \mathrm{~S}\right)$ in $\mu \mathrm{M}$. The station numbers are according to Dale et al. (2015). bdl= below detection limit $(5 \mu \mathrm{M})$.

\begin{tabular}{|c|c|c|c|c|c|c|c|c|c|}
\hline No. & Station & Gear & $\begin{array}{l}\text { Date } \\
\text { (2013) }\end{array}$ & $\begin{array}{l}\text { Longitude } \\
\left({ }^{\circ} \mathrm{W}\right)\end{array}$ & $\begin{array}{l}\text { Latitude } \\
\left({ }^{\circ} \mathrm{S}\right)\end{array}$ & $\begin{array}{l}\text { Water depth } \\
\text { (m) }\end{array}$ & $\begin{array}{l}\mathrm{BW} \mathrm{O}_{2} \\
(\mu \mathrm{M})\end{array}$ & $\begin{array}{l}\mathrm{BW} \mathrm{NO}{ }_{3}^{-} \\
(\mu \mathrm{M})\end{array}$ & $\begin{array}{l}\text { BW } \mathrm{H}_{2} \mathrm{~S} \\
(\mu \mathrm{M})\end{array}$ \\
\hline \multirow[t]{3}{*}{ I } & 98 & CTD26 & 14 Jan & $12^{\circ} 13.504^{\prime}$ & $77^{\circ} 10.799^{\prime}$ & 75 & bdl & - & 33.22 \\
\hline & 220 & MUC39 & $25 \mathrm{Jan}$ & $12^{\circ} 13.531^{\prime}$ & $77^{\circ} 10.061^{\prime}$ & 72 & & & \\
\hline & 110 & BIGO1-2 & $15 \mathrm{Jan}$ & $12^{\circ} 13.506^{\prime}$ & $77^{\circ} 10.793^{\prime}$ & 74 & & & \\
\hline \multirow[t]{3}{*}{ III } & 269 & CTD79 & $29 \mathrm{Jan}$ & $12^{\circ} 16.690^{\prime}$ & $77^{\circ} 14.999^{\prime}$ & 128 & bdl & 0.02 & - \\
\hline & 248 & MUC46 & $27 \mathrm{Jan}$ & $12^{\circ} 16.697^{\prime}$ & $77^{\circ} 15.001^{\prime}$ & 129 & & & \\
\hline & 165 & BIGO2-4 & $20 \mathrm{Jan}$ & $12^{\circ} 16.690^{\prime}$ & $77^{\circ} 14.995^{\prime}$ & 128 & & & \\
\hline \multirow[t]{3}{*}{ IV } & 111 & CTD29 & $15 \mathrm{Jan}$ & $12^{\circ} 18.729^{\prime}$ & $77^{\circ} 17.757^{\prime}$ & 145 & bdl & 7.1 & \\
\hline & 36 & MUC10 & 09 Jan & $12^{\circ} 18.708^{\prime}$ & $77^{\circ} 17.794^{\prime}$ & 145 & & & \\
\hline & 57 & BIGO1-1 & $11 \mathrm{Jan}$ & $12^{\circ} 18.711^{\prime}$ & $77^{\circ} 17.803^{\prime}$ & 141 & & & \\
\hline \multirow[t]{3}{*}{$\mathrm{V}$} & 279 & CTD81 & $30 \mathrm{Jan}$ & $12^{\circ} 21.490^{\prime}$ & $77^{\circ} 21.713^{\prime}$ & 195 & bdl & 6.3 & - \\
\hline & 247 & MUC45 & 27 Jan & $12^{\circ} 21.491^{\prime}$ & $77^{\circ} 21.702^{\prime}$ & 195 & & & \\
\hline & 201 & BIGO1-4 & $23 \mathrm{Jan}$ & $12^{\circ} 21.502^{\prime}$ & $77^{\circ} 21.712^{\prime}$ & 195 & & & \\
\hline \multirow[t]{3}{*}{ VI } & 92 & CTD24 & $13 \mathrm{Jan}$ & $12^{\circ} 23.300^{\prime}$ & $77^{\circ} 24.200^{\prime}$ & 244 & bdl & 11.9 & - \\
\hline & 198 & MUC34 & $23 \mathrm{Jan}$ & $12^{\circ} 23.300^{\prime}$ & $77^{\circ} 24.228^{\prime}$ & 244 & & & \\
\hline & 74 & BIGO2-2 & $12 \mathrm{Jan}$ & $12^{\circ} 23.300^{\prime}$ & $77^{\circ} 24.186^{\prime}$ & 244 & & & \\
\hline \multirow[t]{3}{*}{ VIII } & 66 & CTD16 & 12 Jan & $12^{\circ} 27.535^{\prime}$ & $77^{\circ} 29.593^{\prime}$ & 414 & bdl & 12.1 & - \\
\hline & 107 & MUC23 & $15 \mathrm{Jan}$ & $12^{\circ} 27.198^{\prime}$ & $77^{\circ} 29.497^{\prime}$ & 407 & & & \\
\hline & 207 & BIGO2-5 & $24 \mathrm{Jan}$ & $12^{\circ} 27.207^{\prime}$ & $77^{\circ} 29.517^{\prime}$ & 409 & & & \\
\hline
\end{tabular}

that are driven by the Pacific subtropical anticyclone engender offshore transport of surface waters and upwelling of subsurface waters from the poleward-propagating Peru undercurrent (PUC) (Strub et al., 1998). These water masses are oxygen depleted and rich in nutrients, favoring primary production of up to $3.6 \mathrm{~g} \mathrm{C} \mathrm{m}^{-2} \mathrm{~d}^{-1}$ in surface waters (Pennington et al., 2006). As a consequence, the intense oxygen consumption induced by the degradation of sinking particulate organic matter and a sluggish ventilation causes the development of a strong OMZ. Based on the definition that the oxycline of an OMZ is at $\sim 22 \mu \mathrm{M}$ (Fuenzalida et al., 2009), the Peruvian OMZ extends from approximately 50 to $700 \mathrm{~m}$ water depth. The greatest upwelling strength is reached during austral winter and spring between 5 and $15^{\circ} \mathrm{S}$ (Strub et al., 1998). The phases of strong upwelling are followed by high rates of primary production in austral summer. The coastal area off Peru displays a highly variable hydrographic regime. Especially during positive ENSO periods, coastal trapped waves emerging from equatorial Kelvin waves in the equatorial eastern Pacific occur frequently (Gutiérrez et al., 2008, and references therein; Mosch et al., 2012). Consequently, the thermocline and the oxycline shift downwards by ca. $100 \mathrm{~m}$ and bottom-water oxygen concentrations can increase from practically zero to around $100 \mu \mathrm{M}$ in days to weeks (Gutiérrez et al., 2008; Schunck et al., 2013; Graco et al., 2016). Seasonally, bottom waters of the shelf $(75 \mathrm{~m})$ can transition from oxic or hypoxic between austral winter/spring (low primary production) to anoxic throughout the rest of the year (Noffke et al., 2012). Furthermore, porewater ura- nium profiles at $11^{\circ} \mathrm{S}$ indicate variable redox conditions at the upper rim of the OMZ (Scholz et al., 2011). The shelf area above $200 \mathrm{~m}$ water depth is therefore characterized by non-steady-state conditions, whereas the oxygen concentrations in the core OMZ ( 200-400 m water depth) are predominantly below the detection limit throughout the year.

The sediments of the Peruvian OMZ have POC contents ranging from 15 to $20 \mathrm{wt} \%$ within the $\mathrm{OMZ}$ and $>5 \mathrm{wt} \%$ below the OMZ and on the shelf (Dale et al., 2015). The fine-grained, diatomaceous mud lens between 11 and $15^{\circ} \mathrm{S}$ accumulates under low PUC bottom-water velocities in 50 to $500 \mathrm{~m}$ water depth (Krissek et al., 1980). This favors high sedimentation rates, carbon preservation, and burial (Suess et al., 1987; Dale et al., 2015). Further down, at mid-slope depth, a high-energy regime favoring erosive settings leads to the formation of phosphorites (Reimers and Suess, 1983; Glenn and Arthur, 1988; Arning et al., 2009b; Mosch et al., 2012). Another interesting observation between 70 and $\sim 300 \mathrm{~m}$ of water depth is the occurrence of mat-forming filamentous sulfur bacteria (Mosch et al., 2012). Bacterial mats are not conspicuous below 300 to $400 \mathrm{~m}$ water depth, and instead foraminiferal sands are more common.

\section{Methods}

Sampling of water-column particulate matter and sediment cores as well as the deployment of the benthic landers BIGO I and II (Biogeochemical Observatories) were conducted along the $12^{\circ} \mathrm{S}$ depth transect during RV Meteor cruise 
M92 in January 2013. The geographical position and watercolumn properties for the main stations are reported in Table 1 . The data set on in situ phosphate fluxes comprised 10 stations from 74 to $989 \mathrm{~m}$ water depth. The water-column particle sampling was performed at six stations from 74 to $407 \mathrm{~m}$ water depth. These stations are considered as main stations and for consistency the stations are numbered according to the data set published in Dale et al. (2015). Hydrographic parameters and oxygen concentrations were obtained by deploying a CTD/rosette equipped with a Seabird oxygen sensor (detection limit is $5 \mu \mathrm{M}$ ) calibrated by Winkler titration.

\subsection{Water-column particles}

Particulate matter was filtered using water from Niskin bottles from the $\mathrm{CTD} /$ rosette and analyzed for total particulate phosphorus (TPP), particulate inorganic phosphorus (PIP), and particulate organic carbon (POC) concentrations. Following Labry et al. (2013), we expect the PIP phase to be comprised of inorganic $\mathrm{P}$ phases originating from abiotic particulate $\mathrm{P}$ as well as inorganic $\mathrm{P}$ from biogenic particulate P. Abiotic PIP comprises detrital $\mathrm{P}$ associated with minerals from terrigenous sources. Biotic PIP is composed of orthophosphates, pyrophosphates, and polyphosphates within eukaryotic and prokaryotic cells.

Between three and six water depths were sampled per station. The water was filled into $10 \mathrm{~L} \mathrm{PE}$ containers rinsed beforehand with ultrapure water (MilliQ). The containers were shaken before filtration, which was performed within $24 \mathrm{~h}$ after sample retrieval. Approximately 2 to $4 \mathrm{~L}$ of seawater were filtered through a pre-weighed and combusted $\left(450^{\circ} \mathrm{C}, 5 \mathrm{~h}\right)$ $0.7 \mu \mathrm{M}$ Whatman $\mathrm{GF} / \mathrm{F}$ filter using a seawater vacuum pump and Duran bottle top filters. After filtration, all filters were immediately frozen at $-20^{\circ} \mathrm{C}$. At the shore-based laboratory the $\mathrm{GF} / \mathrm{F}$ filters were dried overnight at $45^{\circ} \mathrm{C}$ and divided into three equally sized pieces using a scalpel. The total filtered water volume was divided by 3 to calculate elemental concentrations on each filter section assuming homogenous coverage of particles on the filters.

\subsubsection{Total particulate phosphorus (TPP), particulate inorganic phosphorus (PIP) and particulate organic phosphorus (POP)}

The determination of TPP and PIP concentrations by combustion and colorimetric methods has been described by Aspila et al. (1976); Loh and Bauer (2000); Asahi et al. (2014), and others.. However, the combustion and acid dissolution (HTC/hydrolysis) that has been applied for PIP determination is limited by the fact that polyphosphates are only partly hydrolyzed, but provides the best compromise compared to other methods (Labry et al., 2013). Although polyphosphates are underestimated, it includes intracellular $\mathrm{P}$ that is often dominant in plankton and only small amounts of organic P. In the case of TPP we used the Aspila (1976) method without an oxidant (e.g., $\mathrm{MgSO}_{4}$ ) during combustion, which underestimates the TPP concentration in water-column particles. However, for the sediments, the results following the Aspila (1976) method were compared to total digestions showing an average recovery of the Aspila method of approximately $102 \%$. In two samples we found an overestimation in total digestion of more than $100 \%$ and, in one sample, an underestimation of $32 \%$, possibly due to heterogeneity of the samples caused by very small phosphorite granules.

Filter segments for TPP concentration were combusted at $550{ }^{\circ} \mathrm{C}$ for $90 \mathrm{~min}$ and afterwards soaked with $20 \mathrm{~mL}$ $1 \mathrm{~N}$ hydrochloric acid $(\mathrm{HCl})$ and shaken for $24 \mathrm{~h}$ at room temperature. Then, the solution was filtered and $0.35 \mathrm{~mL}$ triple reagent $(40 \mathrm{~mL} 9.8 \mathrm{~N}$ sulfuric acid, $12 \mathrm{~mL}$ ammonium molybdate, and $4 \mathrm{~mL}$ potassium antimonyl tartrate solution) and $0.175 \mathrm{~mL}$ ascorbic acid and $3 \mathrm{~mL} 1 \mathrm{~N} \mathrm{HCl}$ were added to $3.75 \mathrm{~mL}$ of the sample solution. Then, $0.3 \mathrm{~mL}$ of $12.5 \mathrm{~N}$ sodium hydroxide $(\mathrm{NaOH})$ was added to the solution before colorimetric measurement of phosphate at $880 \mathrm{~nm}$ using a Hitachi U-2001 photospectrometer. This was done because test runs with the standard series revealed that the slope of the calibration curve was not steep enough to measure the low phosphate concentrations expected. To resolve this issue, the $\mathrm{pH}$ of the solution was slightly increased using $\mathrm{NaOH}$. Measurements were accompanied using a standard series consisting of eight standards ranging from 5 to $100 \mu \mathrm{MPO}_{4}^{3-}$, prepared from a Merck phosphate stock solution. We used $0.75 \mathrm{~mL}$ of each standard for the standard series and treated each of them in the same manner as described above. The samples were measured undiluted due to low concentrations and the technical detection limit of a $1 \mathrm{~cm}$ cuvette. Hence, we used $3.75 \mathrm{~mL}$ of the filtered sample solution, added the reagents mentioned above, and divided the concentrations by a factor of 5 to adjust the results to those of the standard series. A factor of 0.02 was used to transform the concentration unit to $\mu \mathrm{mol} \mathrm{L}^{-1}$. The amount of filtered water $(f)$ refers to $1 / 3$ of the total filtered water volume ( $f$ is different for each sample):

TPP or PIP $\left[\mu \mathrm{molL}^{-1}\right]=\frac{\left[\mathrm{PO}_{4}^{3-}\right] \cdot 0.02}{5 \cdot f}$.

The same procedure was performed for PIP without the combustion step. The POP concentration was calculated by the difference of the measured (as phosphate) TPP and PIP concentrations.

\subsubsection{Organic carbon concentration}

The filter sections for the analysis of POC concentration were fumed with $37 \% \mathrm{HCl}$ overnight to remove inorganic carbon, dried, and wrapped into tin caps. Samples were measured by flash combustion with a Carlo Erba elemental analyzer (NA1500). The analytical precision and detection limit were 0.04 dry wt $\%$. The water-column POC concentrations are given in $\mu \mathrm{mol} \mathrm{L}^{-1}$. 


\subsection{Porewater and solid-phase analysis}

Sediment cores were recovered using video-guided multiple corers (MUCs) equipped with PVC liners with an inner diameter of $10 \mathrm{~cm}$. The porewater and solid-phase subsampling was performed immediately after recovery in an argon-filled glove bag at in situ seafloor temperature. The bottom water was siphoned with a plastic tube and filtered through cellulose acetate filters. Afterwards, the cores were sectioned into $0.5 \mathrm{~cm}$ intervals from 0 to $5 \mathrm{~cm}$ sediment depth and $1 \mathrm{~cm}$ intervals afterwards. The sediment samples were filled into centrifuge tubes and the porewater was separated from the sediments by centrifuging for $20 \mathrm{~min}$ at $\sim 3940 \mathrm{G}$. The supernatant porewater was filtered through cellulose acetate filters inside the glove bag. Samples were immediately analyzed for total dissolved phosphate $\left(\mathrm{TPO}_{4}\right)$ and dissolved ferrous iron $\left(\mathrm{Fe}^{2+}\right)$ after porewater extraction using a Hitachi U-2001 spectrophotometer. The analyses were performed according to the standard techniques described in Grasshoff et al. (1999). A sediment subsample was taken from each sediment depth and stored refrigerated in pre-weighed air-tight plastic cups to determine the water content, porosity, and total organic carbon (TOC) content. The residual sediments were stored frozen at $-20^{\circ} \mathrm{C}$ (sediment and filter samples) and the porewater samples were refrigerated at $4{ }^{\circ} \mathrm{C}$ for landbased analytics.

The TOC concentration (in $\mu \mathrm{mol} \mathrm{mg}^{-1}$ ) of freeze-dried and ground sediment samples was determined by flash combustion in a Carlo Erba Elemental Analyzer (NA 1500). For POC determination, samples were decalcified with $2.5 \mathrm{~N} \mathrm{HCl}$ prior to the measurement. Solid-phase TPP and PIP concentrations were measured according to the method of Aspila et al. (1976) in a similar manner as described above. The $50 \mathrm{mg}$ of freeze-dried and ground sediment were digested in $1 \mathrm{~N} \mathrm{HCl}$ for a minimum of $24 \mathrm{~h}$ to dissolve the sedimentary PIP phase. Sediment portions analyzed for TPP were combusted at $550^{\circ} \mathrm{C}$ for $90 \mathrm{~min}$ before adding $1 \mathrm{~N} \mathrm{HCl}$. The solutions were filtered and the reagents mentioned above were added prior to measurement. We used the sedimentary reference standards SDO-1 (Devonian Ohio Shale, USGS; Govindaraju, 1994) and MESS-3 (Marine Sediment Reference Material, Canadian Research Council) and replicate measurements of samples to ensure measurement accuracy. The standard series applied to the measurements covered a concentration range from 5 to $100 \mu \mathrm{M}$.

To determine the terrigenous $\mathrm{P}$ input to the sediments, and to calculate the TPP burial flux (for calculation, see Sect. 3.6 and Table 2), sediments were analyzed using total digestion. About $100 \mathrm{mg}$ of freeze-dried and ground sediment were digested in hydrofluoric acid (40\%, supra pure), nitric acid (65\%, supra pure), and perchloric acid (60\%, supra pure). For measurement accuracy the reference standards SDO-1 and MESS-3 as well as methodological blanks were included in the analysis. The aluminum concentration in the digestion solutions was measured using an inductively coupled plasma optical emission spectrometer (ICP-OES, Varian 720 ES). The relative standard deviation (RSD) for [Al] was found to be $<1 \%$.

The XRD data of core 107MUC23 from $407 \mathrm{~m}$ water depth were obtained from approximately $1 \mathrm{~g}$ of freeze-dried and ground sediment in the lab of the University of Bremen.

\subsection{POC in relation to various fractions of $\mathrm{P}(\mathrm{POC} / x \mathrm{P}$ ratios)}

The molar POC $/ x \mathrm{P}$ ratios (where $x \mathrm{P}=\mathrm{TPP}$, PIP, or POP) of the water-column particles at stations I, IV, and V were calculated from measurements on two filter samples per water depth. For these samples a minimum and maximum value were calculated. For the other stations III, VI, and VIII, only one sample per water depth was available. Here, we assumed an average natural variability calculated from the duplicate measurements of stations I, IV, and V for each $\mathrm{P}$ species (Supplement). For sediment samples we calculated a standard deviation from repeated measurements of the sediment standards MESS-3 and SDO-1 (Supplement).

\subsection{Benthic lander fluxes}

Benthic lander deployments were performed at 10 stations along the $12^{\circ} \mathrm{S}$ transect (I to $\mathrm{X}$ according to Dale et al., 2015). In situ benthic fluxes were obtained using the two BIGOs I and II (BIGO: Biogeochemical Observatory). They were equipped with two circular flux chambers (internal diameter $28.8 \mathrm{~cm}$, area $651.4 \mathrm{~cm}^{2}$ ) (Sommer et al., 2009). An online video-controlled launch system allowed precise placement of the BIGO at the seafloor directly located beneath the particle sampling stations in the water column and in proximity to the multi-corer stations. After a $4 \mathrm{~h}$ rest period at the seafloor during which surrounding bottom water was periodically flushed into the chamber, the chambers were slowly driven into the sediment. The BIGOs stayed for $28 \mathrm{~h}$ at the seafloor, while eight water samples per chamber were taken via glass syringes. In order to obtain bottom water background information, additional samples were taken every $8 \mathrm{~h}$ from the ambient bottom water. Phosphate concentrations in the syringe samples were measured on board using an auto analyzer. The standard series covered a concentration range from 0.05 to $3.5 \mu \mathrm{M}$. The fluxes were calculated from the slope of linear regression of all eight data points vs. the sampling time (Supplement) and corrected for the water volume in the chamber and the dead volume of the $1 \mathrm{~m}$ long Vygon tubes connecting the syringes with the flux chambers. The error caused by the dilution from the dead volume of these tubes was calculated from the chloride concentration measured in the syringe samples. Benthic lander $\mathrm{TPO}_{4}$ fluxes for most sites are based on two replicate chamber measurements. The uncertainty given for the $\mathrm{TPO}_{4}$ fluxes is the difference between the minimum and maximum fluxes from the average of the two benthic chambers. At two stations (IV and V), 
Table 2. Equations for the P mass balance calculations. Results are shown in Table 4.

\begin{tabular}{|c|c|c|}
\hline \multicolumn{3}{|c|}{$\mathrm{P}$ input to the sediments $\left(\mathrm{mmol} \mathrm{m}^{-2} \mathrm{~d}^{-1}\right)$} \\
\hline (4) & Total particulate phosphorus rain rate & $\mathrm{RR}_{\mathrm{TPP}}=\mathrm{RR}_{\mathrm{PIP}}+\mathrm{RR}_{\mathrm{POP}}=F_{\mathrm{TPO}_{4}}+F_{\mathrm{Pbur}}$ \\
\hline (5) & Particulate inorganic phosphorus rain rate & $\mathrm{RR}_{\mathrm{PIP}}=\mathrm{RR}_{\mathrm{POC}} /\left(\frac{\mathrm{POC}}{\mathrm{PIP}}\right)$ \\
\hline (6) & Particulate organic phosphorus rain rate & $\mathrm{RR}_{\mathrm{POP}}=\mathrm{RR}_{\mathrm{POC}} /\left(\frac{\mathrm{POC}}{\mathrm{POP}}\right)$ \\
\hline (7) & Terrigenous $\mathrm{P}$ input $(\mathrm{P} / \mathrm{Al}=0.02$, Vier et al., 2009) & $\mathrm{RR}_{\text {Pterr }}=\mathrm{Al}_{(0-1)} \cdot \mathrm{MAR} \cdot \frac{\mathrm{P}}{\mathrm{Al}}$ \\
\hline \multicolumn{3}{|c|}{$\mathrm{P}$ burial in the sediments $\left(\mathrm{g} \mathrm{m}^{-2} \mathrm{~d}^{-1}\right)$ at $11 \mathrm{~cm}$} \\
\hline (8) & Phosphorus burial flux & $F_{\mathrm{Pbur}}=\mathrm{MAR} \cdot \mathrm{P}_{11}$ \\
\hline (9) & Mass accumulation rate & $\mathrm{MAR}=\rho_{\mathrm{dry}} \cdot\left(1-\phi_{\infty}\right) \cdot \mathrm{SR}$ \\
\hline$(10)$ & TPP burial efficiency & $\mathrm{PBE}=\mathrm{MAR} \cdot\left(\frac{\mathrm{P}_{11}}{\mathrm{RR}_{\mathrm{TPP}}}\right) \cdot 100 \%$ \\
\hline \multicolumn{3}{|c|}{$\begin{array}{l}\mathrm{P} \text { release from the sediments }\left(\mathrm{mmol} \mathrm{m} \mathrm{m}^{-2} \mathrm{~d}^{-1}\right) \\
\text { Benthic } \mathrm{P} \text { fluxes }\left(\mathrm{F}_{\mathrm{TPO}_{4}}\right) \text { and the potential diffusive } \mathrm{P} \text { fluxes were determined as described in the methods. }\end{array}$} \\
\hline$(11)$ & $\begin{array}{l}\text { P release from POP degradation according to } \\
\text { Redfield }(C / P=106)\end{array}$ & $F_{\mathrm{P}(\mathrm{Red})}=F_{\mathrm{DIC}} / 106$ \\
\hline (12) & True $\mathrm{P}$ release from POP & $F_{\mathrm{P}(\mathrm{POP})}=F_{\mathrm{DIC}} /\left(\frac{\mathrm{POC}}{\mathrm{POP}}\right)$ \\
\hline (13) & P release from total particulate phosphorus & $F_{\mathrm{P}(\mathrm{TPP})}=F_{\mathrm{DIC}} /\left(\frac{\mathrm{POC}}{\mathrm{TPP}}\right)$ \\
\hline (14) & $\begin{array}{l}\mathrm{P} \text { release from the dissolution of } \mathrm{Fe} \text { (oxyhydr)oxides } \\
(\mathrm{Fe} / \mathrm{P}=10 \text {, Slomp et al., 1996) }\end{array}$ & $F_{\mathrm{P}(\mathrm{Fe})}=F_{\mathrm{Fe}^{2+}} /\left(\frac{\mathrm{Fe}}{\mathrm{P}}\right)$ \\
\hline$(15)$ & $\mathrm{P}$ deficit to outbalance the $\mathrm{P}$ budget & $F_{\mathrm{P}(\text { deficit })}=\mathrm{RR}_{\mathrm{TPP}}+\mathrm{RR}_{\text {terr }}+F_{\mathrm{P}(\mathrm{Fe})}-\left(F_{\mathrm{TPO}_{4}}+F_{\mathrm{Pbur}}\right)$ \\
\hline
\end{tabular}

it was only possible to calculate the flux from one chamber. For further details on the benthic flux measurements during the M92 cruise, see Dale et al. (2015).

\subsection{Diffusive flux calculations}

The diffusive fluxes of $\mathrm{TPO}_{4}$ and $\mathrm{Fe}^{2+}$ from the sediment to the bottom water were calculated by applying Fick's first law of diffusion:

$F_{\mathrm{TPO}_{4} / \mathrm{Fe}^{2+}}=-\phi D_{\mathrm{SED}}(\mathrm{d}[C] / \mathrm{d} x)$,

where the term $\mathrm{d}[C] / \mathrm{d} x$ describes the concentration gradient between the bottom water and the first porewater sample of the surface sediment divided by the corresponding sediment depth $(0.25$ or $0.5 \mathrm{~cm})$, and $\phi$ is the porosity of the surface sediment. The diffusion coefficient, $D_{\mathrm{SED}}$, for sediments was calculated accordingly:

$D_{\mathrm{SED}}=D_{\mathrm{SW}} / \theta^{2}$.

The diffusion coefficients for $\mathrm{TPO}_{4}$ and $\mathrm{Fe}^{2+}$ under standard conditions $\left(D_{\mathrm{SW}} ; 298.15 \mathrm{~K}\right.$ and $\left.1 \mathrm{bar}\right)$ were taken from $\mathrm{Li}$ and Gregory (1974) and corrected for the in situ temperature and pressure using the Stokes-Einstein equation. The tortuosity $\left(\theta^{2}\right)$ was derived from the sediment porosity according to the modified Weissberg formulation (Boudreau, 1996):

$\theta^{2}=1-\ln \left(\phi^{2}\right)$.

Uncertainty in the diffusive flux was calculated at station I as the difference between the fluxes calculated from two separate sediment cores. For the other stations, only one core was available to calculate the flux.

\subsection{Mass balance of benthic phosphorus cycling}

To investigate benthic $\mathrm{P}$ cycling quantitatively, a mass balance was developed considering $\mathrm{P}$ input, $\mathrm{P}$ burial, and $\mathrm{P}$ release. The equations for the $\mathrm{P}$ mass balance calculations are shown in Table 2. Under steady-state conditions, the total $\mathrm{P}$ rain rate should balance the $\mathrm{P}$ buried in the sediments and the benthic $\mathrm{TPO}_{4}$ flux (Eq. 4 in Table 2). The rain rates of particulate $\mathrm{P}$ delivered to the sediments are differentiated in inorganic $\mathrm{P}\left(\mathrm{RR}_{\mathrm{PIP}}\right)$ (Eq. 5 in Table 2) and organic $\mathrm{P}$ (RRPOP) (Eq. 6, Table 2). The rates were calculated using the POC $/ x \mathrm{P}$ ratio of the water-column particles that were taken as close as possible to the seafloor at each station (2-5 $\mathrm{m}$ above ground) and the POC rain rate ( $\left.R_{P O C}\right)$ (Table 4 and the Supplement). RR $R_{P O C}$ for the same stations along the $12^{\circ} \mathrm{S}$ transect were previously calculated by Dale et al. (2015) as the sum of the measured benthic DIC flux and the $\mathrm{POC}$ accumulation rate. The terrigenous $\mathrm{P}$ input $\left(\mathrm{RR}_{\mathrm{Pterr}}\right)$ (Eq. 7 in Table 2) can be estimated by multiplying the solidphase $\mathrm{Al}$ concentration of the first sediment sample by the mass accumulation rate (Dale et al., 2015) and a $\mathrm{P} / \mathrm{Al}$ ratio of 0.02 that characterizes the $\mathrm{P} / \mathrm{Al}$ ratio of riverine particles originating from the continent (Viers et al., 2009).

The $\mathrm{P}$ burial flux ( $F_{\text {Pbur }}$ ) (Eq. 8 in Table 2 ) was calculated by multiplying the mass accumulation rate (MAR) and the average solid-phase $\mathrm{P}$ concentration of the first 11 sediment 
(a)
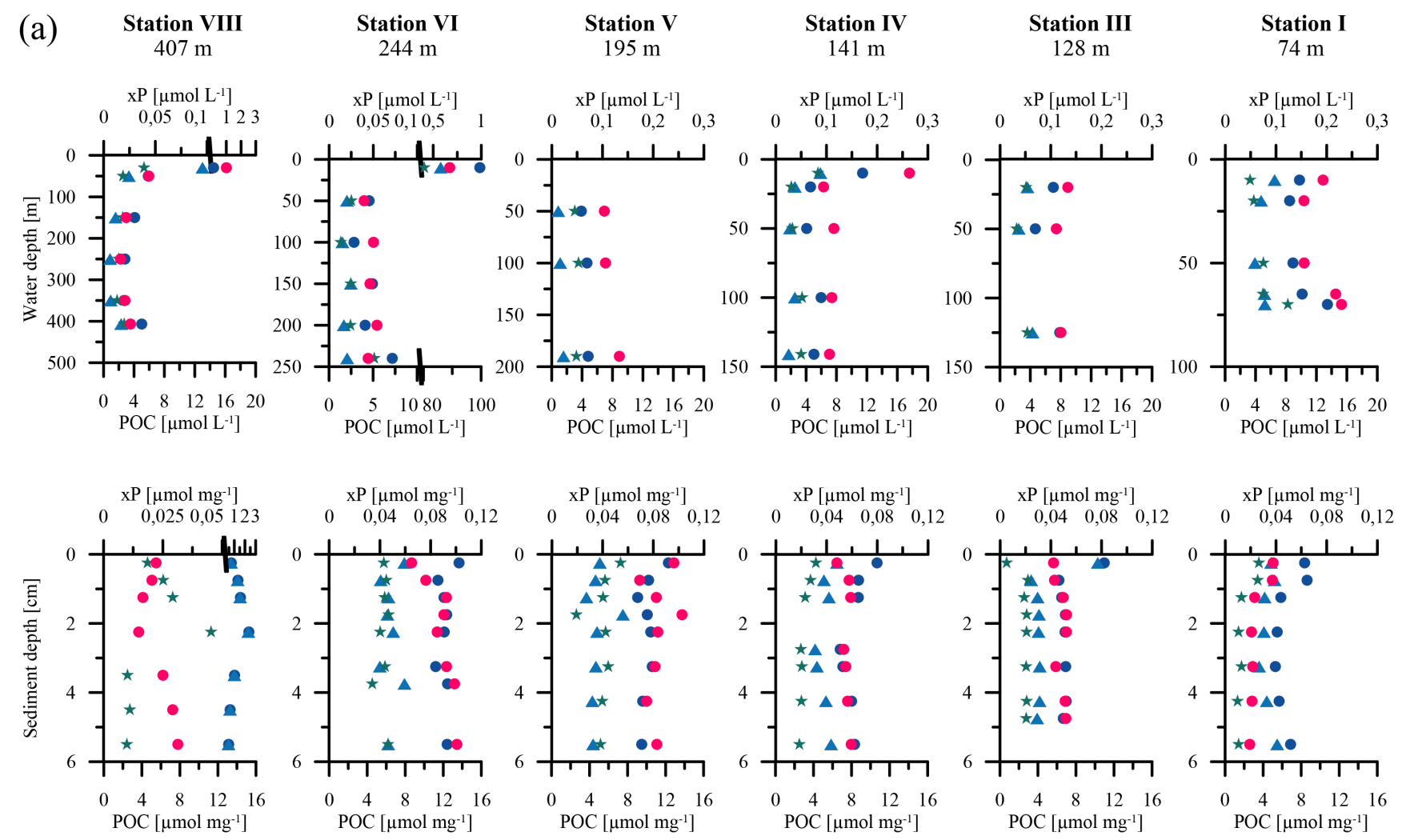

- $\mathrm{TPP} \triangle \mathrm{PIP} \star \mathrm{POP} \bullet \mathrm{POC}$

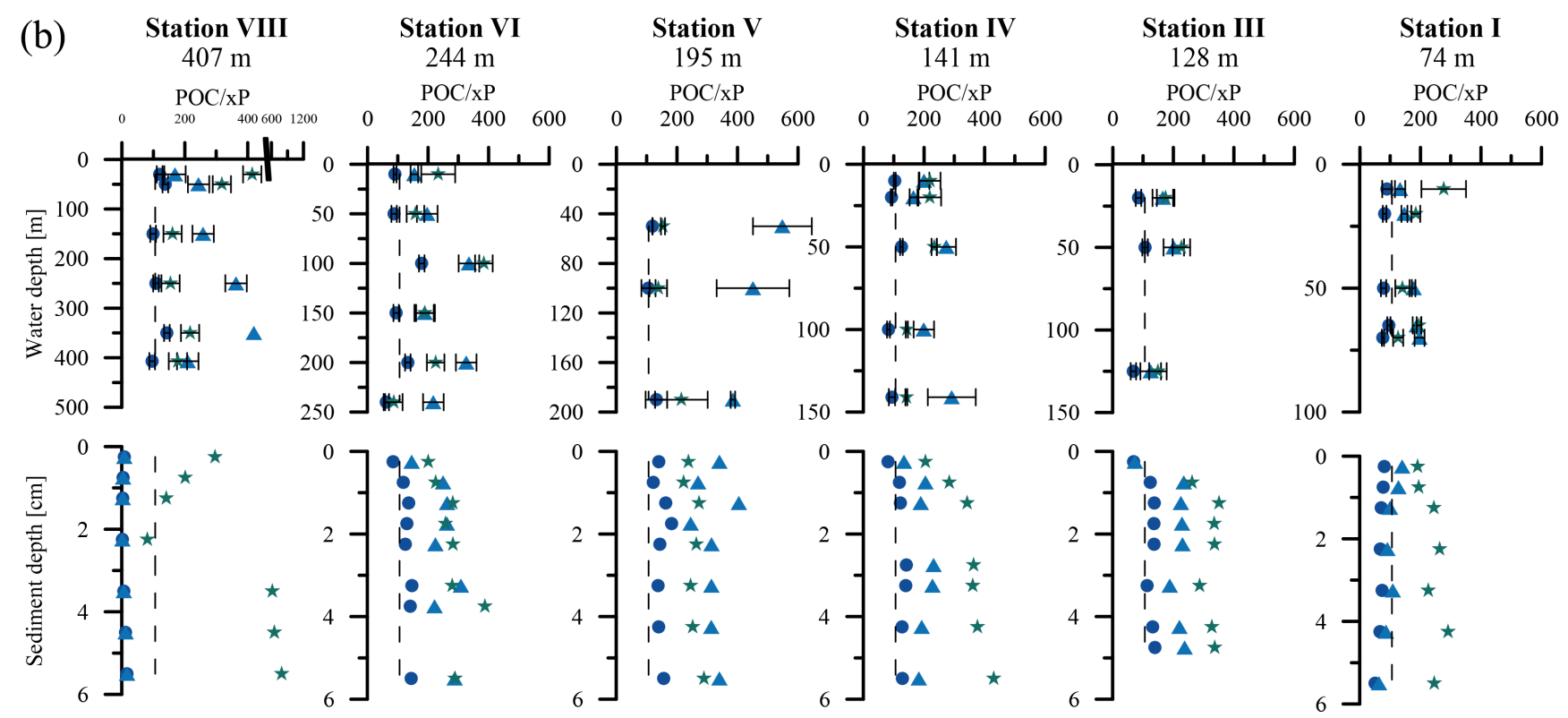

- POC/TPP $\triangle$ POC/PIP $\star$ POC/POP $-\cdots$ Redfield ratio

Figure 2. (a) Concentration profiles of TPP, PIP, POP, and POC of the water-column particles and the surface sediments along the $12^{\circ} \mathrm{S}$ transect. Water-column particle concentrations (upper panel) are given in $\mu \mathrm{mol} \mathrm{L} \mathrm{L}^{-1}$ and surface sediment concentrations (lower panel) are shown in $\mu \mathrm{mol} \mathrm{mg}^{-1}$. Note that the water-column particle concentrations shown for station VI $(244 \mathrm{~m})$ at $10 \mathrm{~m}$ water depth are $\sim 5$ times higher than at the other stations. (b) Ratios of POC to TPP, PIP, and POP (POC / $x \mathrm{P}$ ) along the $12^{\circ} \mathrm{S}$ depth transect of water-column particles and surface sediments (0-5.5 cm depth) of station I to VIII (74 to $407 \mathrm{~m})$. 
centimeters $\left(\mathrm{P}_{11}\right)(11 \mathrm{~cm}$ is due to our sampling resolution). This approach was chosen according to Dale et al. (2015), who also calculated the POC accumulation rate for the OMZ stations (i.e., not on the shelf or below the OMZ) using the elemental average concentration. MAR (Eq. 9 in Table 2) was calculated from the sedimentation rate $\left(\omega_{\mathrm{acc}}\right.$ in $\left.\mathrm{cm} \mathrm{yr}^{-1}\right)$, dry bulk density $\left(\rho_{\text {dry }}\right.$; in $\left.\mathrm{g} \mathrm{cm}^{-3}\right)$, and the average porosity of the sediments at the lower core end. Sedimentation accumulation rates were determined from particle-bound ${ }^{210} \mathrm{~Pb}_{\mathrm{xs}}$ measurements using a modeling approach. A detailed method description and the values used for this work are published in Dale et al. (2015). The error derived from modeling the sedimentation rate was given as $20 \%$ and propagates to all subsequent calculations where it was used.

\subsection{Freeze-thaw experiments}

In order to determine the amount of polyphosphate stored in sulfide-oxidizing bacteria, foraminifera, and other bacteria, we conducted additional sediment experiments at all transect stations except station IV. Sediments from MUC corers were sliced into $1 \mathrm{~cm}$ thick slices from the surface sediment to $10 \mathrm{~cm}$ sediment depth. Before phosphate analysis, sediment slices were repeatedly frozen at $-80^{\circ} \mathrm{C}$ and defrosted in order to burst microbial cells and release the internally stored $\mathrm{P}$ to the porewater.

\subsection{Molecular quantification of filamentous bacteria}

In order to quantify the abundance of filamentous microbes at the benthic boundary layer, we used a molecular approach. Nucleic acid purification was performed on $0.5 \mathrm{~g}$ sediment following established protocols (Bertics et al., 2013). DNA was quality checked on an agarose gel and quantified using a NanoDrop spectrophotometer (Peqlab, Erlangen, Germany). The 16S rDNA fragments were taken from a previously generated metagenome from this region (GenBank Bioproject PRJNA280940) and the respective sequence countings were deposited at GenBank (ID KU312264-KU312267). Sequencing was carried out in the Institute of Clinical Molecular Biology at Kiel University. Sequences were analyzed using a Clustal W alignment tool on Mega 6 (Tamura et al., 2013). A qPCR primer and probe set was established using the Primer Express software (Life Technologies, Carlsbad, USA) with the forward primer 5'AGAAGCACCGGCTAACTCTG-3', the reverse primer $5^{\prime}$-CCAGGTAAGGTTCTTCGCGT- $3^{\prime}$, and probe 829 -Thioploca $5^{\prime}$-GGATTAATTTCCCCCAACAT-3' (Teske et al., 1995). Primers and probes were tested in silico on the Silva database and cross amplification was excluded on a variety of $16 \mathrm{~S}$ rDNA clones. The qPCRs were performed in technical duplicates on a ViiA7 system (Life Technologies, Carlsbad, USA) as previously described (Löscher et al., 2012) using a $1 \times$ TaqMan PCR buffer (Life Technologies, Carlsbad, USA), a $2.5 \mathrm{pmol} \mu \mathrm{L}^{-1}$ TaqMan probe,
5 pmol $\mu \mathrm{L}^{-1}$ of each primer, $400 \mathrm{ng} \mu \mathrm{L}^{-1}$ bovine serum albumin (to avoid PCR inhibition without affecting standard curves or detection limits), $3 \mu \mathrm{L}$ PCR water, and $5 \mu \mathrm{L}$ of either standard DNA or environmental sample. A plasmid containing the target sequence was used to generate a standard dilution series for absolute quantification. The melting temperature was set to $50^{\circ} \mathrm{C}$. A theoretical detection limit of four copies per PCR reaction was calculated. The results of the analysis are given in copies $\mathrm{g}^{-1}$ of $16 \mathrm{~S}$ rDNA sequences of sulfur bacteria that are related to Marithioploca.

\section{Results}

\subsection{P composition of water-column particulate matter and surface sediments}

\subsubsection{TPP, PIP, POP and POC concentrations}

The TPP concentrations ranged from 0.02 to $0.2 \mu \mathrm{mol} \mathrm{L}^{-1}$ in the water-column particles and from 0.04 to $2.37 \mu \mathrm{mol} \mathrm{mg}^{-1}$ in the surface sediments (Supplement). Overall, the profiles along the transect show no significant trends through the water column (Fig. 2a). The highest concentrations occurred in the surface waters around $10 \mathrm{~m}$ of water depth. At stations I, V, and VIII $(74,195$, and $407 \mathrm{~m})$, the TPP concentrations slightly increased close to the seafloor, whereas at the other stations no such trend was observed (Fig. 2a and the Supplement). In the sediments the TPP concentrations slightly decreased with sediment depth, except at station VIII $(407 \mathrm{~m})$. Here, the highest sedimentary TPP concentrations across the transect were found at $2.25 \mathrm{~cm}$ sediment depth $\left(17 \mu \mathrm{mol} \mathrm{mg}{ }^{-1}\right)$. Below that depth the concentrations decreased, but remained high compared to the other stations.

The PIP and POP concentrations (water column and sediments) generally followed the trends of the TPP profiles and contributed roughly equally to TPP. The PIP fraction accounted for 21 to $74 \%$ of TPP in the water-column particles (Fig. 3), similar to that reported in previous studies (Paytan et al., 2003; Faul et al., 2005; Benitez-Nelson et al., 2007; Lyons et al., 2011; Sekula-Wood et al., 2012). At stations I, VI, and VIII (74, 244, and $407 \mathrm{~m}$ ), the PIP concentrations were larger than POP. The opposite occurred at station V $(195 \mathrm{~m})$, where the POP fraction was clearly larger than the PIP fraction throughout the entire water column. In comparison to the water-column particles, the sedimentary PIP fraction was larger than POP in most samples, reaching between 48 and $98 \%$ of TPP. However, the strongest deviation between PIP and POP concentrations was found in the sediments of station VIII $(407 \mathrm{~m})$, where the PIP concentration was up to a factor of $\sim 50$ larger than the POP concentration and comprised up to $98 \%$ of TPP. XRD data from that station revealed that 7 to $16 \mathrm{wt} \%$ of the sediments consisted of apatite and other P-bearing minerals (data not shown). 

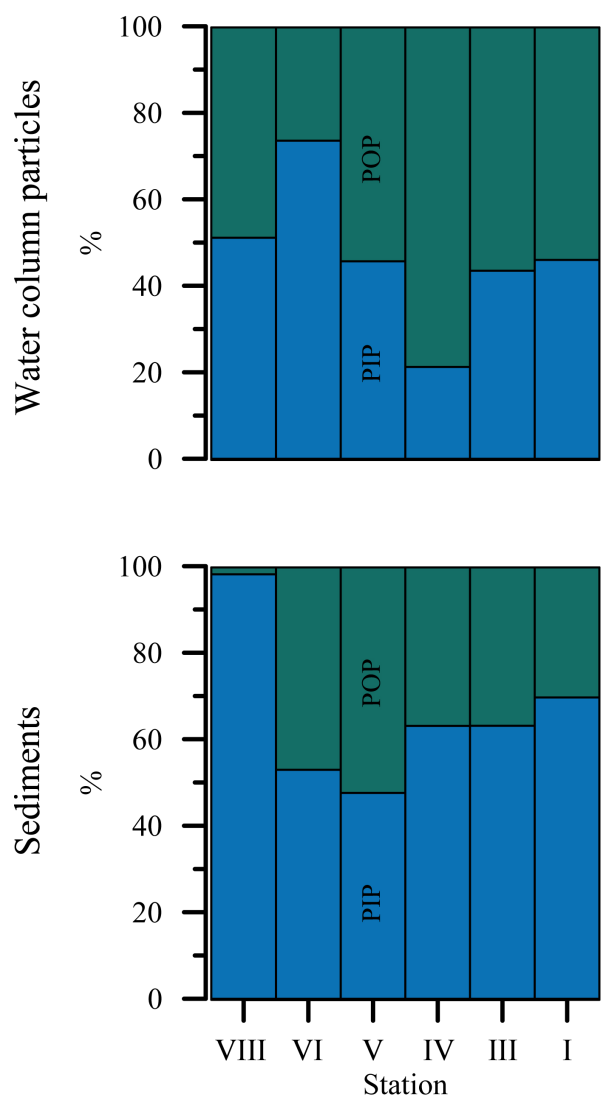

Figure 3. Average distribution of POP and PIP (\%) per station in the water-column particles and in the top $5.5 \mathrm{~cm}$ of the sediments.

The particulate organic carbon concentrations ranged from 2.2 to $17.6 \mu \mathrm{mol} \mathrm{L}^{-1}$ in the water-column particles and from 2.8 to $13.4 \mu \mathrm{mol} \mathrm{mg}{ }^{-1}$ in the surface sediments. Within the water column the highest concentrations occurred in the surface water samples, while the concentration measured at station VI $(244 \mathrm{~m})$ is about 5 times higher compared to other samples from the same water depth. Below the surface water concentration peak, the concentrations were on average $7 \mu \mathrm{mol} \mathrm{L}{ }^{-1}$ with distinct depth trends. The sedimentary POC concentrations were on average $7.7 \mu \mathrm{mol} \mathrm{mg}^{-1}$ for the whole transect. Overall, the POC concentrations showed little variability with sediment depth. At stations III, VI, and VIII $(128,244$, and $407 \mathrm{~m})$, the concentrations increased slightly with sediment depth. At station I (74 m) the concentration decreased slightly with sediment depth.

\subsection{Particulate organic carbon to phosphorus (POP, PIP, TPP) ratios}

\subsubsection{POC / POP ratios}

The molar POC / POP ratios of the water-column particles and of the surface sediments were consistently higher than the Redfield ratio of 106 (Redfield, 1963) at all stations
(Fig. 2b). The average POC / POP ratio of the water-column particles was $202 \pm 29$. There was no clear trend through the water column, except for slightly increasing ratios between the deepest water-column samples and the surface sediment samples. In the surface sediments, the ratios increased within the upper $6 \mathrm{~cm}$ with an average POC / POP ratio of $303 \pm 77$. Station VIII $(407 \mathrm{~m})$ is an exception, and here the ratio decreased to 81 within the first $\sim 2 \mathrm{~cm}$ of sediment and then strongly increased to $\geq 600$.

\subsubsection{POC / PIP ratios}

The average POC / PIP ratio of the water-column particles was $248 \pm 34$. Similar to the POC / POP ratios, there was no significant trend through the water column. At the majority of the stations, the ratios decreased close to the seabed. The average POC / PIP ratio of the surface sediments was $184 \pm 34$ and almost invariable with water depth. In the sediments, the ratios showed no significant down-core trend. At station VIII $(407 \mathrm{~m})$ the ratio in the sediments showed a dramatic decrease compared to the water column, with an average of 7, similar to the POC / TPP ratios (below).

\subsubsection{POC / TPP ratios}

The POC / TPP ratios of the water-column particles and surface sediments consistently varied around the Redfield ratio. The exceptions are station I $(74 \mathrm{~m})$ and the deepest station (station VIII, $407 \mathrm{~m}$ ). At station I, the sediments showed significantly lower than Redfield ratios, with an average of 69 in the surface sediments. The average POC / TPP ratio of the surface sediments at station VIII (407 m) was 7. Between the deepest water-column sample and the first sediment sample, the POC / TPP ratios were rather constant without a consistent trend, again with the exception of station VIII (407 m), where the ratios decreased sharply.

\subsection{In situ benthic chamber fluxes}

The benthic lander $\mathrm{TPO}_{4}$ fluxes $\left(F_{\mathrm{TPO}_{4}}\right)$ are presented in Table 3 and Fig. 4a. Positive fluxes are defined as directed from the sediments into the water column. The highest $\mathrm{TPO}_{4}$ flux along the depth transect of $1.04 \pm 0.31 \mathrm{mmol} \mathrm{m}^{-2} \mathrm{~d}^{-1}$ occurred at station I $(74 \mathrm{~m})$. Below $74 \mathrm{~m}$ water depth, fluxes decreased by at least a factor of 3 to $0.2-$ $0.3 \mathrm{mmol} \mathrm{m}^{2} \mathrm{~d}^{-1}$ at $144 \mathrm{~m}$ water depth. Measurements at station V $(195 \mathrm{~m})$ showed a slightly increased $\mathrm{TPO}_{4}$ flux of $0.44 \pm 0.07 \mathrm{mmol} \mathrm{m}^{-2} \mathrm{~d}^{-1}$, while the fluxes measured at $244 \mathrm{~m}$ (station VI) and $306 \mathrm{~m}$ (station VII) decreased to the levels mentioned before. At $407 \mathrm{~m}$ water depth (station VIII), the $\mathrm{TPO}_{4}$ flux was negative, indicating a phosphate uptake by the sediment. Below the OMZ, the fluxes increased to slightly positive values, but remained low at 0.06 and $0.02 \pm 0.02 \mathrm{mmol} \mathrm{m}^{-2} \mathrm{~d}^{-1}$. 
Table 3. In situ benthic chamber $\mathrm{TPO}_{4}$ fluxes in $m m o l m^{-2} \mathrm{~d}^{-1}$ along the $12^{\circ} \mathrm{S}$ transect. The numbers are shown as an average and standard deviation calculated from the minimum and maximum fluxes determined from two benthic chambers.

\begin{tabular}{lll}
\hline Station & Water depth & $F_{\mathrm{TPO}_{4}}$ \\
\cline { 2 - 3 } & $(\mathrm{m})$ & $\left(\mathrm{mmol} \mathrm{m}^{-2} \mathrm{~d}^{-1}\right)$ \\
\hline I BIGO1_2 & 74 & $1.04 \pm 0.31$ \\
II BIGO1_5 & 101 & $0.35 \pm 0.01$ \\
III BIGO2_4 & 128 & $0.30 \pm 0.05$ \\
IV BIGO1_1 & 141 & $0.23^{*}$ \\
V BIGO1_4 & 195 & $0.12^{*}$ \\
VI BIGO2_2 & 243 & $0.44 \pm 0.07$ \\
VII BIGO2_1 & 306 & $0.26 \pm 0.04$ \\
VIII BIGO2_5 & 409 & $-0.07^{*}$ \\
IX BIGO2_3 & 756 & $0.06^{*}$ \\
X BIGO1_3 & 989 & $0.02 \pm 0.02$ \\
\hline
\end{tabular}

* Only one benthic flux was measured.

\subsubsection{Comparison of benthic chamber $\mathrm{TPO}_{4}$ fluxes and diffusive $\mathrm{TPO}_{4}$ fluxes}

The measured benthic chamber $\mathrm{TPO}_{4}$ fluxes and the calculated diffusive $\mathrm{TPO}_{4}$ fluxes showed large discrepancies. The calculated diffusive fluxes were consistently higher than the benthic fluxes (Table 4, Fig. 4b). In contrast to the in situ measured benthic chamber $\mathrm{TPO}_{4}$ release rates, the calculation of diffusive $\mathrm{TPO}_{4}$ fluxes relies on bottom water and porewater $\mathrm{PO}_{4}^{3-}$ concentrations. A subsurface $\mathrm{PO}_{4}^{3-}$ peak occurred at all stations in the uppermost depth interval at $0-0.25 \mathrm{~cm}$, causing a large concentration gradient between the bottom water and the porewater $\mathrm{PO}_{4}^{3-}$ concentrations (Fig. 7). Even though the measured benthic $\mathrm{TPO}_{4}$ fluxes exceeded the fluxes that could be generated by TPP degradation by a factor of approximately 6 , the diffusive $\mathrm{TPO}_{4}$ fluxes were still higher (Table 4). Hence, the diffusive $\mathrm{TPO}_{4}$ flux will be referred to as potential $\mathrm{TPO}_{4}$ flux in the following.

\subsection{TPP burial fluxes and TPP burial efficiency}

The $\mathrm{P}$ burial fluxes decreased with increasing water depth (Table 4). Station I ( $74 \mathrm{~m}$ ) showed by far the highest $\mathrm{P}$ burial flux, with $0.23 \mathrm{mmol} \mathrm{m}^{-2} \mathrm{~d}^{-1}$. In contrast, the P burial efficiency at this station (Eq. 10) was comparatively low, reaching only approximately $26 \%$. At station VIII $(407 \mathrm{~m})$, the TPP burial flux was $13 \mathrm{mmol} \mathrm{m}^{-2} \mathrm{~d}^{-1}$, and the $P$ burial efficiency exceeded $100 \%$ due to the uptake of dissolved $P$ from ambient bottom waters.

\subsection{Molecular analysis and relative abundance of filamentous sulfur bacteria}

Molecular analysis indicated the presence of Marithioplocarelated bacteria (Salman et al., 2011) in the surface sediments
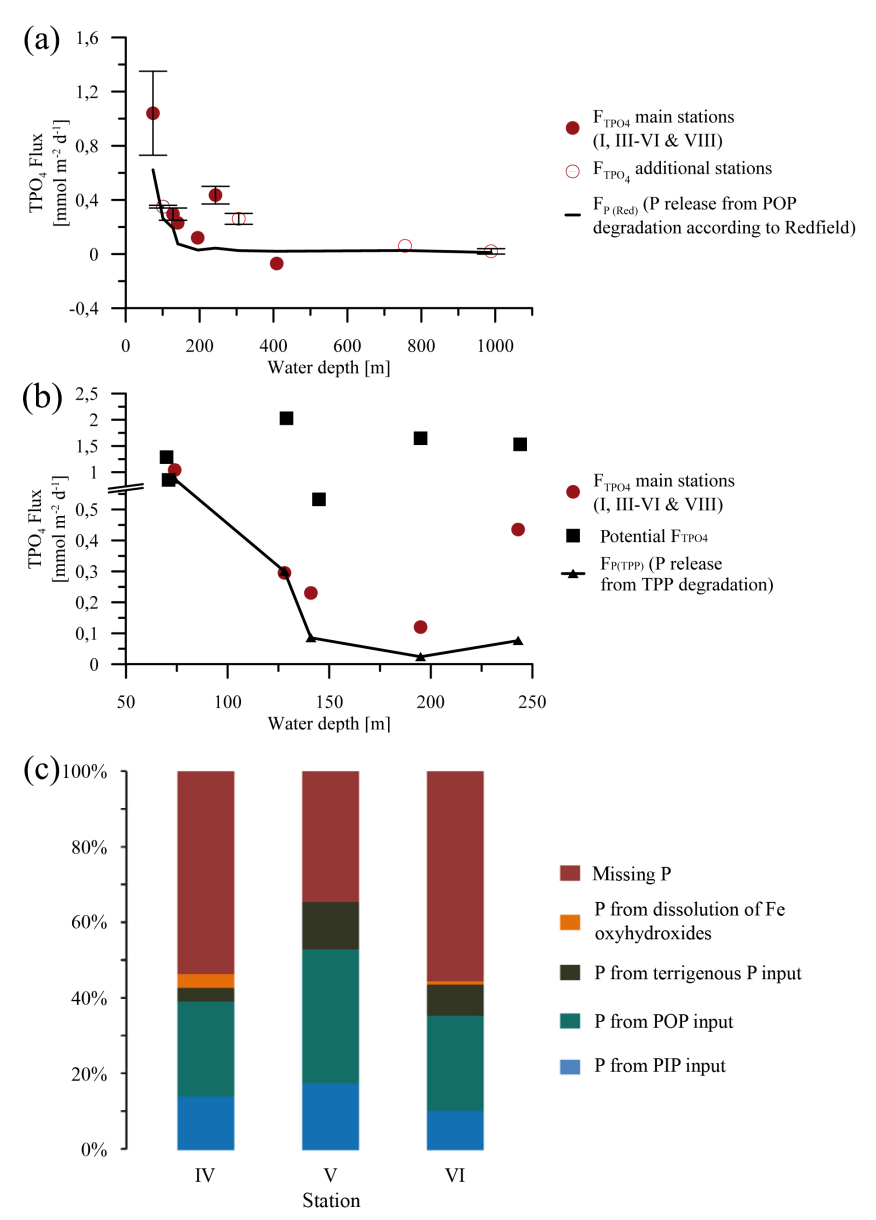

Figure 4. (a) Measured benthic $\mathrm{TPO}_{4}$ fluxes $\left(\mathrm{mmol} \mathrm{m}-2 \mathrm{~d}^{-1}\right)$ at $12^{\circ} \mathrm{S}$. The black line shows the theoretical $\mathrm{TPO}_{4}$ flux generated from organic matter degradation with a Redfield POC / POP ratio of 106. (b) Potential $\mathrm{TPO}_{4}$ fluxes $\left(\mathrm{mmol} \mathrm{m}^{-2} \mathrm{~d}^{-1}\right)$ calculated from porewater profiles compared to the measured benthic $\mathrm{TPO}_{4}$ fluxes ( $\mathrm{mmol} \mathrm{m} \mathrm{m}^{-2} \mathrm{~d}^{-1}$ ) at stations I to VIII (74 to $407 \mathrm{~m}$ ). The black line with triangles depicts the $\mathrm{TPO}_{4}$ flux that could be generated during degradation of total particulate phosphorus. (c) $\mathrm{P}$ percentages of the different $\mathrm{P}$ sources and the missing $\mathrm{P}$ that is needed to maintain the measured $\mathrm{TPO}_{4}$ release rates and $\mathrm{P}$ burial fluxes for stations IV, V, and VI (141, 195, and $244 \mathrm{~m})$ of transect section II. The missing P is assumed to be supplied by sulfide-oxidizing Marithioploca-related bacteria (see Discussion).

$(0-5 \mathrm{~cm})$. Our analysis may, however, underestimate the absolute abundance of these organisms due to a self-splicing mechanism of the 16S rDNA gene (Salman et al., 2012) and is therefore only indicative for their relative abundance.

The relative abundance of Marithioploca-related bacteria decreased with increasing water depth (Table 4). The highest relative abundance with more than 4000 copies $^{-1}$ sediment was found at station $\mathrm{I}(74 \mathrm{~m})$, decreasing by more than a factor of 20 to 190 copies $^{-1}$ sediment at station VIII (407 m). 
Table 4. Measured and calculated parameters for the $\mathrm{P}$ mass balance along the $12^{\circ} \mathrm{S}$ transect. The numbers in front of key parameters correspond to equations in Table 2.

\begin{tabular}{|c|c|c|c|c|c|c|}
\hline \multirow[b]{2}{*}{$12^{\circ} \mathrm{S}$} & \multicolumn{2}{|c|}{ Transect section I } & \multicolumn{3}{|c|}{ Transect section II } & \multirow{2}{*}{$\begin{array}{l}\text { Phosphorite formation } \\
\text { Station VIII } \\
407 \mathrm{~m}\end{array}$} \\
\hline & $\begin{array}{l}\text { Station I } \\
74 \mathrm{~m}\end{array}$ & $\begin{array}{l}\text { Station III } \\
128 \mathrm{~m}\end{array}$ & $\begin{array}{l}\text { Station IV } \\
141 \mathrm{~m}\end{array}$ & $\begin{array}{l}\text { Station V } \\
195 \mathrm{~m}\end{array}$ & $\begin{array}{l}\text { Station VI } \\
244 \mathrm{~m}\end{array}$ & \\
\hline Benthic chamber $\mathrm{TPO}_{4}$ flux $\left(F_{\mathrm{TPO}_{4}}\right)^{1} \mathrm{mmol} \mathrm{m}^{-2} \mathrm{~d}^{-1}$ & $1.04 \pm 0.31$ & $0.3 \pm 0.05$ & 0.23 & 0.12 & $0.44 \pm 0.07$ & -0.07 \\
\hline Benthic diffusive $\mathrm{TPO}_{4}$ flux (potential flux) $\mathrm{mmol} \mathrm{m}^{-2} \mathrm{~d}^{-1}$ & $1.07 \pm 0.23$ & 2.0 & 0.5 & 1.6 & 1.5 & \\
\hline $\begin{array}{l}\text { Relative abundance of Marithioploca-related bacteria }{ }^{1} \text { copies } \mathrm{g}^{-1}(0-5 \mathrm{~cm} \text { sediment } \\
\text { depth) }\end{array}$ & 4159 & & 1687 & 3072 & & 190 \\
\hline Benthic chamber DIC flux $\left(F_{\mathrm{DIC}}\right)^{2} \mathrm{mmol} \mathrm{m}^{-2} \mathrm{~d}^{-1}$ & $65.9 \pm 21$ & $20.4 \pm 7$ & $8 \pm 0.4$ & $3.2 \pm 1$ & $4.7 \pm 1$ & $2.2 \pm 0.3$ \\
\hline POC rain rate $\left(\mathrm{RR}_{\mathrm{POC}}\right)^{2} \mathrm{mmol} \mathrm{m}^{-2} \mathrm{~d}^{-1}$ & $79.5 \pm 33$ & $28.2 \pm 12$ & $10.5 \pm 3$ & $12.5 \pm 6$ & $10.6 \pm 4$ & $2.7 \pm 1$ \\
\hline Sediment accumulation rate $\left(\omega_{\mathrm{acc}}\right)^{2} \mathrm{~cm} \mathrm{yr}^{-1}$ & $0.45 \pm 0.09$ & $0.2 \pm 0.04$ & $0.04 \pm 0.008$ & $0.1 \pm 0.02$ & $0.07 \pm 0.014$ & $0.01 \pm 0.002$ \\
\hline Mass accumulation rate $(\mathrm{MAR})^{2} \mathrm{~g} \mathrm{~m}^{-2} \mathrm{yr}^{-1}$ & $1800 \pm 360$ & $600 \pm 120$ & $128 \pm 26$ & $320 \pm 64$ & $182 \pm 37$ & $44 \pm 9$ \\
\hline \multicolumn{7}{|l|}{ Ratios for particulate matter from the water column ( 2 to $5 \mathrm{~m}$ above the sea floor): } \\
\hline $\mathrm{POC} / \mathrm{TPP}^{1}$ & $76 \pm 4$ & $68 \pm 9$ & $94 \pm 10$ & $132 \pm 36$ & $62 \pm 9$ & $96 \pm 9$ \\
\hline $\mathrm{POC} / \mathrm{PIP}^{1}$ & $197 \pm 17$ & $125 \pm 34$ & $291 \pm 79$ & $385 \pm 7$ & $217 \pm 34$ & $209 \pm 34$ \\
\hline $\mathrm{POC} / \mathrm{POP}^{1}$ & $126 \pm 17$ & $149 \pm 29$ & $142 \pm 3$ & $214 \pm 87$ & $87 \pm 29$ & $178 \pm 29$ \\
\hline (4) TPP rain rate $\left(\mathrm{RR}_{\mathrm{TPP}}\right) \mathrm{mmol} \mathrm{m}^{-2} \mathrm{~d}^{-1}$ & $1.00 \pm 0.31$ & $0.40 \pm 0.09$ & $0.11 \pm 0.02$ & $0.09 \pm 0.02$ & $0.17 \pm 0.02$ & $0.03 \pm 0.01$ \\
\hline (5) PIP rain rate (RRPIP) $\mathrm{mmol} \mathrm{m}^{-2} \mathrm{~d}^{-1}$ & $0.39 \pm 0.14$ & $0.22 \pm 0.04$ & $0.04 \pm 0$ & $0.03 \pm 0.02$ & $0.05 \pm 0.01$ & $0.01 \pm 0.01$ \\
\hline (6) POP rain rate $\left(\mathrm{RR}_{\mathrm{POP}}\right) \mathrm{mmol} \mathrm{m}^{-2} \mathrm{~d}^{-1}$ & $0.61 \pm 0.18$ & $0.18 \pm 0.05$ & $0.07 \pm 0.02$ & $0.06 \pm 0.01$ & $0.12 \pm 0.01$ & $0.01 \pm 0.01$ \\
\hline (7) Terrigenous $P$ input $\left(R_{P t e r r}\right)$ & 0.10 & 0.02 & 0.01 & 0.02 & 0.01 & 0.00 \\
\hline (8) Burial flux $\left(F_{\mathrm{Pbur}}\right)$ in $11 \mathrm{~cm}$ sediment depth $\mathrm{mmol} \mathrm{m}^{-2} \mathrm{~d}^{-1}$ & 0.23 & 0.09 & 0.02 & 0.08 & 0.04 & 0.13 \\
\hline Avg. Al conc. $(0-1 \mathrm{~cm}$ sediment $)\left(\mathrm{Al}_{0-1}\right)^{1} \mathrm{mmol} \mathrm{g}^{-1}$ & 0.99 & 0.70 & 1.10 & 0.97 & 0.72 & 0.66 \\
\hline Avg. $\mathrm{P}$ conc. $(0-11 \mathrm{~cm}$ sediment $)\left(\mathrm{P}_{11}\right)^{1} \mathrm{mmol} \mathrm{g}^{-1}$ & 0.05 & 0.05 & 0.07 & 0.09 & 0.08 & 1.05 \\
\hline (10) P burial efficiency (PBE) at $11 \mathrm{~cm}$ sediment depth $\%$ & $26 \pm 8$ & $23 \pm 4$ & $23 \pm 5$ & $92 \pm 20$ & $23 \pm 2$ & $490 \pm 100$ \\
\hline (11) $\mathrm{P}$ release from POP degradation according to Redfield $\left(F_{\mathrm{P}(\mathrm{Red})}\right) \mathrm{mmol} \mathrm{m}^{-2} \mathrm{~d}^{-1}$ & $0.62 \pm 0.2$ & $0.19 \pm 0.06$ & $0.08 \pm 0.01$ & $0.03 \pm 0.01$ & $0.04 \pm 0.02$ & $0.02 \pm 0$ \\
\hline (12) $\mathrm{P}$ release from POP degradation $\left(F_{\mathrm{P}(\mathrm{POP})}\right) \mathrm{mmol} \mathrm{m}^{-2} \mathrm{~d}^{-1}$ & $0.52 \pm 0.16$ & $0.14 \pm 0.05$ & $0.06 \pm 0.01$ & $0.02 \pm 0.01$ & $0.05 \pm 0.02$ & $0.01 \pm 0$ \\
\hline (13) $\mathrm{P}$ release from TPP degradation $\left(F_{\mathrm{P}(\mathrm{TPP})}\right) \mathrm{mmol} \mathrm{m}^{-2} \mathrm{~d}^{-1}$ & $0.87 \pm 0.17$ & $0.3 \pm 0.1$ & $0.09 \pm 0.01$ & $0.02 \pm 0.01$ & $0.08 \pm 0.02$ & $0.02 \pm 0.01$ \\
\hline Diffusive $\mathrm{Fe}^{2+}$ flux $\left(F_{\mathrm{Fe}^{2+}}\right)^{1}$ & $0.04 \pm 0.02$ & 0.01 & 0.02 & 0.0 & 0.03 & 0.0 \\
\hline (14) $\mathrm{P}$ release from $\mathrm{Fe}$ (oxyhydr)oxides $\left(F_{\mathrm{P}(\mathrm{Fe})}\right) \mathrm{mmol} \mathrm{m}^{-2} \mathrm{~d}^{-1}$ & $0.004 \pm 0.002$ & 0.001 & 0.002 & 0.0 & 0.003 & 0.0 \\
\hline (15) $\mathrm{P}$ deficit to outbalance the $\mathrm{P}$ budget $\left(F_{\mathrm{P}(\text { deficit })}\right) \mathrm{mmol} \mathrm{m}^{-2} \mathrm{~d}^{-1}$ & & & 0.12 & 0.09 & 0.3 & \\
\hline
\end{tabular}

1 This study; ${ }^{2}$ published data from Dale et al. (2015)

\section{Discussion}

\subsection{POC / $x$ P ratios in water-column particles and sediments}

In order to characterize the fate of $\mathrm{P}$ in oxygen-deficient waters and sediments, we determined POC / $x \mathrm{P}$ ratios from both environments. Previous studies focused either on the water column or on the sediments (Anderson et al., 2001, and references therein; Benitez-Nelson et al., 2004; Faul et al., 2005; Jilbert et al., 2011; Lyons et al., 2011; Sekula-Wood et al., 2012). The present data set provides a more complete insight into compositional changes and allows us to more rigorously constrain the sedimentary $\mathrm{P}$ mass balance compared to earlier studies (Ingall and Jahnke, 1994; Mort et al., 2010; Kraal et al., 2012; Noffke, 2014).

Both water-column particles and the surface sediments from the Peruvian OMZ displayed POC / POP ratios above Redfield, indicating depletion of organic $\mathrm{P}$ relative to organic C. Similar observations have been reported before from this and other regions of the ocean (Loh and Bauer, 2000; Benitez-Nelson et al., 2004; Faul et al., 2005; Franz et al., 2012, and others). Preferential remineralization of $P$ phases from sinking particles should lead to increasing POC / POP ratios with increasing water depth, as observed in oxygenated areas of the ocean (reviewed by Ruttenberg, 2014). However, in the anoxic Cariaco Basin, no such preferential P mineralization was noted (Benitez-Nelson et al., 2004). Our results also showed no clear decrease in the POC / POP ratio in the water column, with the possible exception of stations I and VIII. Higher than Redfield POC / POP ratios have been observed previously in Peru, and may instead be driven by the C-to-P composition of the diatomaceous phytoplankton communities (Franz et al., 2012) rather than preferential P dissolution or other controls such as the input of terrestrial plant material with high POC / POP ratios.

Preferential POP over POC remineralization in anoxic sediments remains controversial (Ingall and Van Cappellen, 1990; Ingall and Jahnke, 1994; Colman et al., 1997; Anderson et al, 2001; McManus et al., 1997; Ruttenberg, 2003; Jilbert et al., 2011). Our results showed no clear trend across all stations. At stations I, IV, and VI (74, 141, and $244 \mathrm{~m})$, the POC / POP increased with sediment depth, indicating preferential POP over POC remineralization. At station III (128 m) this trend occured only in the upper $\mathrm{cm}$, and at station $\mathrm{V}$ (195 m) no preferential POP over POC remineralization was found. POC / POP ratios at station VIII (407 m) showed a POP enrichment over the upper $2 \mathrm{~cm}$ of the sediment. Below this depth, there was a sudden increase in POC / POP ratios, which is likely due to intense POP remineralization and subsequent authigenic formation of phosphorites (sinkswitching; see Sect. 5.2.3).

Another interesting finding pointing to sink-switching can be found in the POC / POP and POC / PIP ratios of the deepest water-column particle sample and the first sediment sample at stations I, IV, VI, and VIII (74, 141, 244, and $407 \mathrm{~m})$. 
Increasing POC / POP and decreasing POC / PIP ratios indicate that POP is converted into PIP while the TPP content of the sediment is conserved (Fig. 2a and b). In agreement with similar findings in anoxic sediments (Ruttenberg and Berner, 1993; Faul et al., 2005, and others), we assume that the observed POP to PIP transformation is due to the formation of CFA. However, our results emphasize that sink-switching is obviously occurring at the interface between bottom waters and sediments.

Interestingly, the water-column POC / TPP ratios were close to the Redfield ratio. This could be an effect of surface adsorption of $\mathrm{P}$ on phytoplankton as previously described by Sanudo-Wilhelmy et al. (2004). Those authors investigated different species of Trichodesmium from the Atlantic Ocean and found that the intracellular P pool was strongly depleted relative to $\mathrm{C}$, whereas the combination of the intracellular plus surface adsorbed $\mathrm{P}$ was close to the Redfield ratio. Although we did not exactly differentiate between internal and external $\mathrm{P}$ pools, and considering that additional $\mathrm{P}$ sources like terrigenous $\mathrm{P}$ are negligible (see Sect. 5.2.1), our results generally support the findings of Sanudo-Wilhelmy et al. (2004). However, future studies are required to substantiate this hypothesis.

Sedimentary POC / TPP ratios were also close to Redfield, except at stations I and VIII (74 and $407 \mathrm{~m}$ ). Thus, on the one hand, the sink switching mechanism operates efficiently under low-oxygen conditions and, on the other hand, the relative degradations of TPP and POC do not change from the water column to the sediments (Fig. 2b). This is an important finding because at first sight this observation seems to be inconsistent with the long-standing paradigm that lowoxygen conditions promote the enhanced release of dissolved P from sediments (Van Cappellen and Ingall, 1996). However, it should be noted that marine sediments covered by oxygenated bottom waters display molar POC / TPP ratios ranging from about 10 to 50 (Baturin, 2007). These ratios are much lower than Redfield because $P$ is retained in sediments via adsorption, authigenic mineral precipitation such as $\mathrm{Fe}$ (oxyhydr)oxides and microbial $\mathrm{P}$ sequestration (Ingall and Jahnke, 1994), and because POC is more efficiently degraded under aerobic conditions (Hedges et al., 1999; Wallmann, 2010). In contrast, our data set implies that oxygen deficiency causes a shift of POC / TPP ratios to values closer to Redfield compared to oxygenated regions, which is due to both, the enhanced preservation of POC (Dale et al., 2015) and release of dissolved phosphate under low-oxygen conditions. It remains puzzling why the extreme $\mathrm{P}$ depletion observed in some black shale sequences (e.g., POC / TPP > 3000, Ingall and Jahnke, 1994) is not found in modern anoxic sediments such as those on the Peru margin.

\subsection{P mass balance}

$P$ release rates from sediments underlying oxygen-deficient waters are strongly enhanced compared to oxygenated ma- rine settings, especially in the Peruvian OMZ (Noffke et al., 2012, 2016). Nonetheless, the sources of the enhanced P release are still not completely identified. The widely held view is that POP raining from the water column to the sediments represents the main source of sedimentary $\mathrm{P}$ in high productive areas like the Peru upwelling system (Delaney, 1998; Filippelli, 2008). Mass balance approaches that resolve the $\mathrm{P}$ regeneration vs. burial in oxygen-deficient environments by combining sedimentary data and benthic $\mathrm{P}$ fluxes are rare (Ingall and Jahnke, 1994; Ingall et al., 2005; Mort et al., 2010; Kraal et al., 2012; Noffke, 2014). These studies are all based on sediment data only; that is, the external $\mathrm{P}$ input to the sediments is estimated or ignored. Furthermore, the study areas were often not covered by fully anoxic bottom waters. Noffke (2014) presented an approach that combines measurements of solid-phase $\mathrm{P}$ speciation, sediment burial fluxes, and benthic chamber flux measurements for a mass balance on benthic P cycling in the Peruvian OMZ. Interestingly, the measurements on the solid-phase $\mathrm{P}$ speciation revealed that organic P accounted for only $18-37 \%$ of the total sedimentary $\mathrm{P}$ on the shelf and upper slope (Noffke, 2014). Furthermore, it was found that $P$ bound to Fe (oxyhydr)oxides and terrigenous $\mathrm{P}$ was of minor importance for the total sedimentary P inventory. However, authigenic $\mathrm{Ca}-\mathrm{P}$ with a high amount of fish-P accounted for up to $47 \%$ of the total $\mathrm{P}$ in sediments down to $300 \mathrm{~m}$ water depth and for up to $70 \%$ in sediments below $300 \mathrm{~m}$ water depth. Consequently, Noffke (2014) suggested that authigenic $\mathrm{Ca}-\mathrm{P}$ phases are an additional major $\mathrm{P}$ source besides organic $\mathrm{P}$ for benthic $\mathrm{P}$ release in the Peruvian OMZ.

Their mass balance approach was solely based on benthic work and has large uncertainties regarding the particulate $\mathrm{P}$ input from the water column. Our approach includes the particulate organic and inorganic $\mathrm{P}$ input from the water column, benthic P flux measurements, and the $\mathrm{P}$ burial fluxes, and is based on the steady-state assumption that the $\mathrm{P}$ input has to be sufficient to maintain the benthic $\mathrm{P}$ flux and $\mathrm{P}$ burial flux. The P mass balance calculations (Table 4) illustrate the variability in $\mathrm{TPO}_{4}$ release and burial as well as in the magnitude of particulate organic (Fig. 5a) and particulate inorganic $\mathrm{P}$ input (Fig. 5b) across the transect. Following the general assumption that POP is the major P phase delivered to the sediments (Delaney, 1998; Filippelli, 2008), we first calculated whether the rain rate of POP $\left(R_{P O P}\right)$ to the seafloor can account for the measured benthic $\mathrm{P}$ fluxes $\left(F_{\mathrm{TPO}_{4}}\right)$ and $\mathrm{P}$ burial fluxes $\left(F_{\mathrm{Pbur}}\right)(\mathrm{Fig} .5 \mathrm{a}$, Table 4$)$. However, as already suggested by Noffke et al. (2012) and Noffke (2014), the POP fraction is far too small to balance the measured benthic fluxes in the Peruvian OMZ. The POP rain rates calculated along the transect can account for only 25 to $48 \%$ of the measured $\mathrm{TPO}_{4}$ fluxes (Fig. 5a), suggesting the likely presence of an additional inorganic source of dissolved phosphate (Noffke, 2014). Similar to previous studies (Paytan et al., 2003; Faul et al., 2005; Benitez-Nelson et al., 2007; Lyons et al., 2011; Sekula-Wood et al., 2012), we found that 
the PIP fraction in water-column particles ranging from 75 to $407 \mathrm{~m}$ water depth comprises between 21 and $74 \%$ of TPP (Fig. 3). In the sediments, the average PIP fraction rises to 48-98\% of TPP (Fig. 3). Furthermore, POC and PIP were correlated $\left(r^{2}=0.74\right)$ in the water-column particles, indicating highly reactive material.

The mass balance approach including the PIP rain rate to the seafloor (Fig. 5b) allows the depth transect to be divided into two sections. The transect section I (station I, $74 \mathrm{~m}$, and III, $128 \mathrm{~m}$ ) is characterized by high $\mathrm{P}$ input and release rates. The calculations on the $\mathrm{P}$ budget show a balance between the particulate $\mathrm{P}$ input, the benthic $\mathrm{P}$ fluxes, and the $\mathrm{P}$ burial fluxes within the error margin $( \pm 20 \%)$. In transect section II (stations IV, $141 \mathrm{~m}, \mathrm{~V}, 195 \mathrm{~m}$, and VI, $244 \mathrm{~m}$ ), the P input decreases drastically (Fig. 5b, Table 4), whereas the benthic $\mathrm{P}$ fluxes are still comparatively high. The distinct mismatch in $\mathrm{P}$ input and $\mathrm{P}$ output prevails as the particulate $\mathrm{P}$ rain rates supported only 37 to $53 \%$ of the measured $\mathrm{TPO}_{4}$ fluxes and calculated burial fluxes. This leads to the question: what drives the excess $\mathrm{TPO}_{4}$ release in the core of the Peruvian OMZ?

\subsubsection{Additional P input}

Besides the particulate matter raining to the sediments, other potential P sources can be considered. Firstly, riverine transported material from the continent may be an additional source of $\mathrm{P}$ to the sediments. Due to fast sinking speed and laterally dominated transport it is possible that this $\mathrm{P}$ fraction is at least underrepresented on the filter samples. In order to provide a maximum estimate for the contribution of the terrigenous $\mathrm{P}$ input to the sediments, this fraction was calculated using the mass accumulation rate of $\mathrm{Al}$ in the first centimeter of sediment and an average molar $\mathrm{P} / \mathrm{Al}$ ratio (Table 2) of 0.02 for riverine suspended particles (Viers et al., 2009). The resulting terrigenous $P$ flux accounted for 5-19\% of the total $\mathrm{P}$ input, which is insufficient to explain the observed discrepancies in the P budget of transect section II (Table 4, Fig. 4c, 5b).

Laterally transported particles enriched in $\mathrm{P}$ from the very shallow shelf could be an additional P source (e.g., Jahnke, 1990). However, the particles would need to be strongly enriched in $\mathrm{P}$, which is not the case. In addition, this would have to be reflected in the POC / TPP ratios of the surface sediments in transect section II (Fig. 2b). The ratios are not, or are only slightly, enriched in TPP compared to the watercolumn particles, which leads to the conclusion that lateral transport of P-enriched particles to the sediments is an unlikely candidate for the missing $\mathrm{P}$ source.

Another alternative is the existence of an additional PIP phase supplied by fast-sinking material (e.g., P containing fish scales; Suess, 1981) that was not sampled during CTD casts, and hence is underrepresented on our filter samples. Díaz-Ochoa et al. (2009) showed that fish P can make up to $20 \%$ of the total sedimentary P inventory in the shelf sed- iments of the Peruvian OMZ. Fish $\mathrm{P}$ input should be depicted in low sedimentary POC / TPP ratios compared to the water-column particles. Since this difference is not observed, fish debris can be ruled out for closing the $\mathrm{P}$ budget during the sampling campaign. Theoretically, sediments need to be composed of particles having POC / TPP ratios between $11 \pm 1$ and $25 \pm 12$ (Table 4 ) to maintain the measured $P$ release rates in transect section II. It seems unlikely that the mismatch in the $\mathrm{P}$ mass balance is caused by additional particles deposited at the seabed since their POC / TPP ratio would need to be much lower than any value observed in our data set.

\subsubsection{Non-steady-state scenarios - internal sedimentary $P$ pools}

Besides an additional $\mathrm{P}$ input to the sediments from the water column, episodic dissolution of particulate $\mathrm{P}$ within the sediment could contribute to the excess $P$ release (Noffke et al., 2012). This could include $\mathrm{P}$ solubilized from $\mathrm{Fe}$ (oxyhydr)oxides or the degradation of internally stored polyphosphates within sulfide-oxidizing bacteria. Driving factors could include the temporal variability in bottomwater oxygen and nutrient concentrations induced by the passage of internal Kelvin waves and/or interannual variability related to El Niño and La Niña (Guitérrez et al., 2008).

It is well recognized that the sedimentary cycles of Fe and $\mathrm{P}$ are strongly linked (e.g., Sundby et al., 1986). Fe (oxyhydr)oxides are expected to be important carriers for phosphorus from the water column to the sediments. Following dissolution of solid Fe minerals in the sediments, the adsorbed $\mathrm{P}$ is released into the porewaters. However, in the Peruvian $\mathrm{OMZ}$, oxygen concentrations in the water column are generally below the detection limit. Consequently, Fe (oxyhydr)oxides are likely already dissolved in the water column and not such an important $\mathrm{P}$ source to the sediments. An estimate of phosphate released during the reduction of $\mathrm{Fe}$ (oxyhydr)oxides can be calculated from the diffusive $\mathrm{Fe}^{2+}$ fluxes and the molar $\mathrm{Fe} / \mathrm{P}$ ratio typically found in $\mathrm{Fe}$ (oxyhydr)oxides. The diffusive $\mathrm{Fe}^{2+}$ fluxes were in the range of 0 to $0.03 \mathrm{mmol} \mathrm{m}{ }^{-2} \mathrm{~d}^{-1}$ during the M92 cruise (Table 4), and the molar Fe / $\mathrm{P}$ ratio of $\mathrm{Fe}$ (oxyhydr)oxides in sediment is around 10 (Slomp et al., 1996). The calculation of the $\mathrm{TPO}_{4}$ release rates from $\mathrm{Fe}$ (oxyhydr)oxides (Eq. 14 in Table 2) results in a flux of $0.003 \mathrm{mmol} \mathrm{PO}_{4}^{3-} \mathrm{m}^{-2} \mathrm{~d}^{-1}$ (Table 4, Fig. 4c, and $5 \mathrm{~b}$ ), which is equivalent to less than $5 \%$ of the benthic $\mathrm{P}$ flux and burial flux.

An additional internally activated $\mathrm{P}$ pool is phosphate released from large sulfur-oxidizing bacteria, e.g., Beggiatoa (Sannigrahi and Ingall, 2005; Brock and Schulz-Vogt, 2011). These microorganisms store $\mathrm{P}$ in the form of intracellular polyphosphate granules when terminal electron acceptors for sulfide oxidation are available (oxic and nitrogenous conditions) and release dissolved $\mathrm{P}$ during periods when these oxidants are scarce (anoxic conditions). Hence, it is generally 
Transect section II

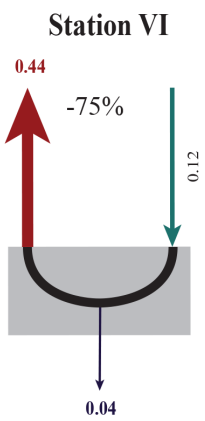

Input $<$ Output

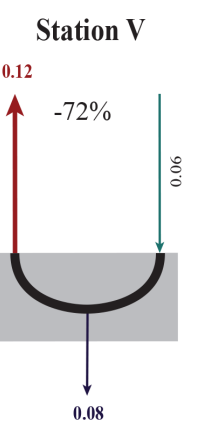

Input $<$ Output

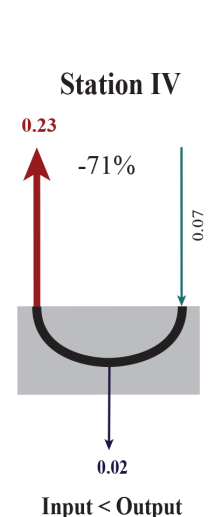

Input $<$ Output

POP rain rate

PIP rain rate
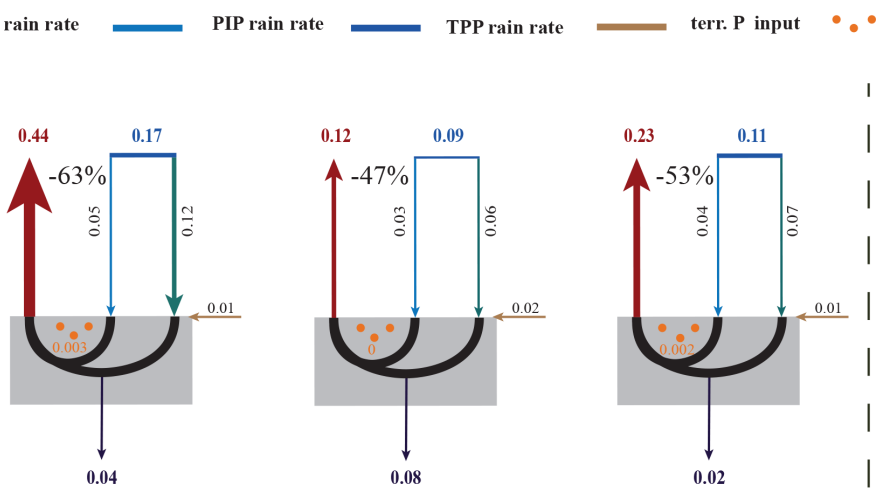

Input $<$ Output

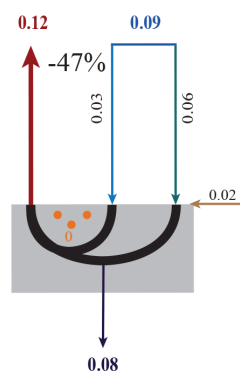

Input $<$ Output
Transect section I

Station III

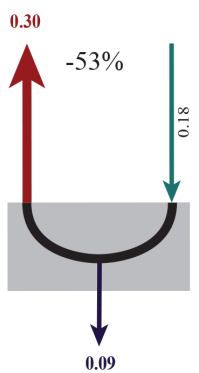

Input $<$ Output

I

(a)

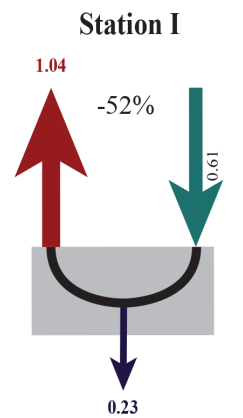

Input $<$ Output

P input from diss. Fe oxyhydroxides

P burial flux

benthic F TPO4

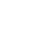

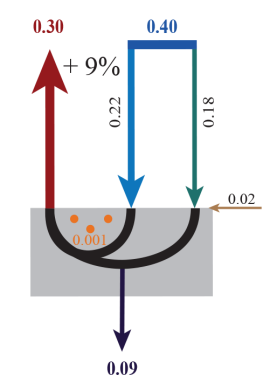

Input $\leq$ Output

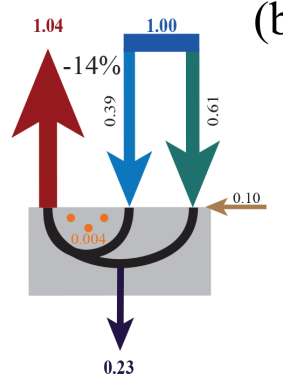

Input $\leq$ Output

Figure 5. Mass balance calculations and measured benthic $\mathrm{TPO}_{4}$ fluxes for stations I to VIII (74 to $407 \mathrm{~m}$ ). All fluxes are in mmol $\mathrm{m}^{-2} \mathrm{~d}^{-1}$ : (a) $\mathrm{POP}$ rain rates, $\mathrm{TPO}_{4}$ fluxes, and $\mathrm{P}$ burial rates only. The number in percent denotes missing $\mathrm{P}$ needed to sustain the benthic $\mathrm{TPO}_{4}$ fluxes. (b) Mass balance calculations including the POP and PIP rain rates, the terrigenous P input, P release from the reductive dissolution of Fe (oxyhydr)oxides and the benthic $\mathrm{TPO}_{4}$ fluxes into the bottom waters, as well as the $\mathrm{P}$ burial rates.

assumed that they strongly affect benthic $\mathrm{TPO}_{4}$ fluxes in a system with frequently changing bottom water redox conditions (Ingall and Jahnke, 1994; Sannigrahi and Ingall, 2005; Schulz and Jørgensen, 2005; Brock and Schulz-Vogt, 2011; Dale et al., 2013). Polyphosphates have been shown to be an important $\mathrm{P}$ pool in the sediments of highly productive upwelling areas (Kraal et al., 2015). Along the depth transect at Peru, dense mats of sulfur bacteria related to Marithioploca were observed on the sediments during video-launched MUC and benthic lander deployments down to $300 \mathrm{~m}$ water depth (Dale et al., 2015). Similar findings that extended distributions of microbial mats along a latitudinal transect at $11^{\circ} \mathrm{S}$ were also previously described by Mosch et al. (2012) and Gutiérrez et al. (2008). Although these organisms are not known to store polyphosphates like their close relatives, Beggiatoa spp. and Thiomargarita spp. (Høgslund et al., 2009; Holmkvist et al., 2010), our findings provide circumstantial indications of $\mathrm{P}$ uptake and release by Marithioploca-related bacteria.

Firstly, we found that the relative abundance of copies of Marithioploca-related bacteria per $\mathrm{g}^{-1}$ sediment and the measured benthic $\mathrm{TPO}_{4}$ release rates correlate linearly $\left(r^{2}=0.92\right.$, Fig. 6$)$. This finding supports the suggestion that bacteria exert an important control on benthic P fluxes. Secondly, a comparison of the in situ measured benthic $\mathrm{P}$ fluxes and the diffusive $\mathrm{P}$ fluxes calculated from the difference of the $\mathrm{TPO}_{4}$ bottom water concentration and the $\mathrm{TPO}_{4}$ porewater concentration of the surface sediments revealed large differences (Fig. 4b). Such a difference could be explained by the lysis of bacterial cells during sample retrieval followed by the release of the internally stored polyphosphate pool into the porewater. Following this argument, the diffusive $\mathrm{P}$ fluxes cannot be taken as real fluxes, but as a measure for potential maximum release rates of $\mathrm{P}$ by Marithioploca-related bacteria. It should be noted that the potential fluxes are more than sufficient to compensate for the missing $\mathrm{P}$ fraction in transect section II (ranging from 0.5 to $1.6 \mathrm{mmol} \mathrm{m}^{-2} \mathrm{~d}^{-1}$; Table 4, Fig. 4b).

In addition to the established porewater extraction procedure, we carried out freeze-thaw experiments to quantify the amount of $\mathrm{P}$ stored in sulfide-oxidizing bacteria (see the method in Sect. 3.7). The released polyphosphates from the 


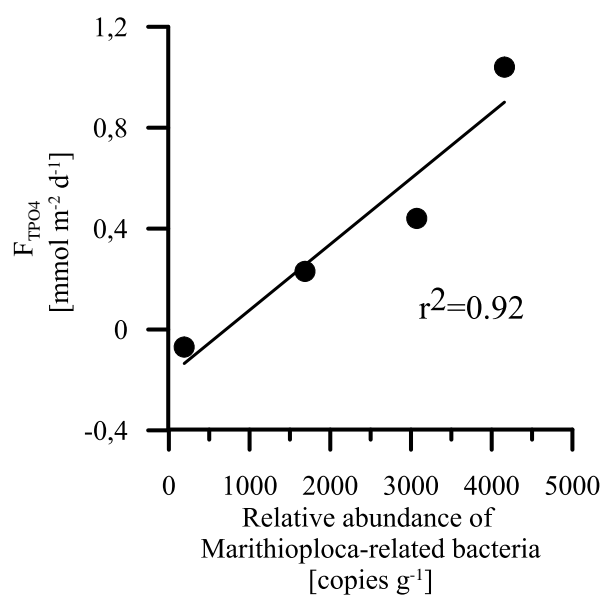

Figure 6. Measured $\mathrm{TPO}_{4}$ fluxes vs. relative abundance of Marithioploca in cells $\mathrm{g}^{-1}$ in the upper $5 \mathrm{~cm}$ of the sediment. Highest abundance and $\mathrm{TPO}_{4}$ flux were found at station I. The other data points are for stations IV, VI, and VIII (with decreasing abundance and $\mathrm{TPO}_{4}$ flux).

microbial cells after repeated freeze-thaw cycles are rapidly hydrolyzed to orthophosphate under acidic conditions (de Jager and Heyns, 1998). Hence, the standard method to determine phosphate in the porewaters using acidic reagents will favor the hydrolysis of polyphosphates, enabling us to measure its concentration in the porewaters after conducting the experiments. However, this method cannot exclude $\mathrm{P}$ release from other bacteria and, possibly, foraminifera in the sediments. A comparison of the porewater phosphate concentrations and the experiment results shows that the amount of the internal $\mathrm{P}$ reservoir is twice as high as the porewater $\mathrm{P}$ concentration in transect section I and more than 10 times higher in transect section II (Fig. 7). These results are coincident with the findings from the mass balance approach, where the largest discrepancies occur in transect Sect. II and are another indication of the bacterial impact on the benthic P release. Interestingly, the highest phosphate concentrations after the freeze-thaw experiments were found at station VIII (407 m) with abundant foraminifera rather than sulfide-oxidizing bacteria. Hence, we assume that the sulfide-oxidizing bacteria at stations IV, V, and VI $(141,194$, and $244 \mathrm{~m})$ and, potentially, the foraminifera observed at station VIII $(407 \mathrm{~m})$, are contributing phosphate to the porewaters. To our knowledge, $\mathrm{P}$ storage by foraminifera has not been demonstrated previously and awaits further study.

It remains to be shown how these mechanisms play out in detail (e.g., nutrient concentration thresholds, P uptake and release timescales by Marithioploca-related bacteria) and how they impact benthic P release in oxygen- and nitratedeficient environments on longer timescales. Summarizing the results of the mass balance, it should be noted that, even with the relevant data on particulate $P$ rain rates, the benthic $\mathrm{P}$ mass balance for the core of the Peruvian OMZ is imbal- anced and requires an additional $\mathrm{P}$ source to maintain the benthic $\mathrm{TPO}_{4}$ fluxes. We suggest that sulfur bacteria make an important contribution to this missing $\mathrm{P}$ source.

\subsubsection{Indications for active phosphorite formation}

In contrast to the stations between 74 and $244 \mathrm{~m}$ water depth characterized by P release, data from station VIII at $407 \mathrm{~m}$ water depth indicate the uptake of phosphate from the bottom water. To our knowledge, this is the first time that a downward flux of dissolved phosphate from bottom waters into phosphorite-bearing surface sediments has been documented by in situ benthic flux measurements. Furthermore, the PIP concentrations in the surface sediments of station VIII (Fig. 2a) were 10 to 60 times higher compared to the shallower stations where $\mathrm{P}$ was released from the sediments. Taken together, these observations indicate that a PIP phase, likely phosphorite, is precipitating from the porewater phosphate at the time of sampling. This is also reflected in decreasing porewater phosphate concentrations (Fig. 7).

Arning et al. (2008) presented investigations on phosphorites recovered from the Peruvian OMZ, including a station at $12^{\circ} \mathrm{S}$ from the same water depth $(\sim 400 \mathrm{~m})$ close to sampling station VIII. The suboxic bottom waters and low sedimentation rates in that area seem to be favorable for phosphorite formation close to the sediment-water interface (Arning et al., 2009b). Cosmidis et al. (2013) suggested three mechanisms for how high porewater phosphate concentrations that are essential for the phosphogenesis can be generated in the sediments: (1) remineralization of organic matter mainly through bacterial sulfate reduction releasing phosphate to the porewaters, (2) reductive dissolution of Fe (oxyhydr)oxides and the release of adsorbed P, and (3) synthesis of internally stored polyphosphates by large sulfide-oxidizing bacteria. Using the same mass balance approach as presented before, we calculate a $\mathrm{P}$ accumulation rate of $33 \pm 4 \mathrm{mmol} \mathrm{m}^{-2} \mathrm{yr}^{-1}$ at station VIII, where most of the $\mathrm{P}$ is derived from ambient bottom waters $\left(26 \mathrm{mmol} \mathrm{m}^{-2} \mathrm{yr}^{-1}\right)$. Hence, our data suggest that the phosphorite nodules at this station contain phosphate that originates predominantly from ambient bottom waters. Additionally, as already mentioned, sediments at station VIII were covered by benthic foraminifera instead of mat-forming sulfur bacteria. The release of phosphate from frozen samples from this site may indicate that these foraminifera are a source of polyphosphates (see Sect. 3.7 and Fig. 7). Our observations suggest that benthic foraminifera rather than bacterial mats might facilitate the uptake of bottom water phosphate and the formation of phosphorites at this station. However, this remains an open question and should be addressed in future field campaigns.

The $\mathrm{P}$ uptake rate of $\sim 26 \mathrm{mmol} \mathrm{P} \mathrm{m}^{-2} \mathrm{yr}^{-1}$ derived from our lander measurements may be compared to previous estimates on phosphorite growth rates in the area. Dating of phosphoric laminites yields a $\mathrm{P}$ uptake rate of only $3 \mathrm{mmol} \mathrm{P} \mathrm{m}^{-2} \mathrm{yr}^{-1}$ for a ca. 1 Ma old nodule (Arning et al., 


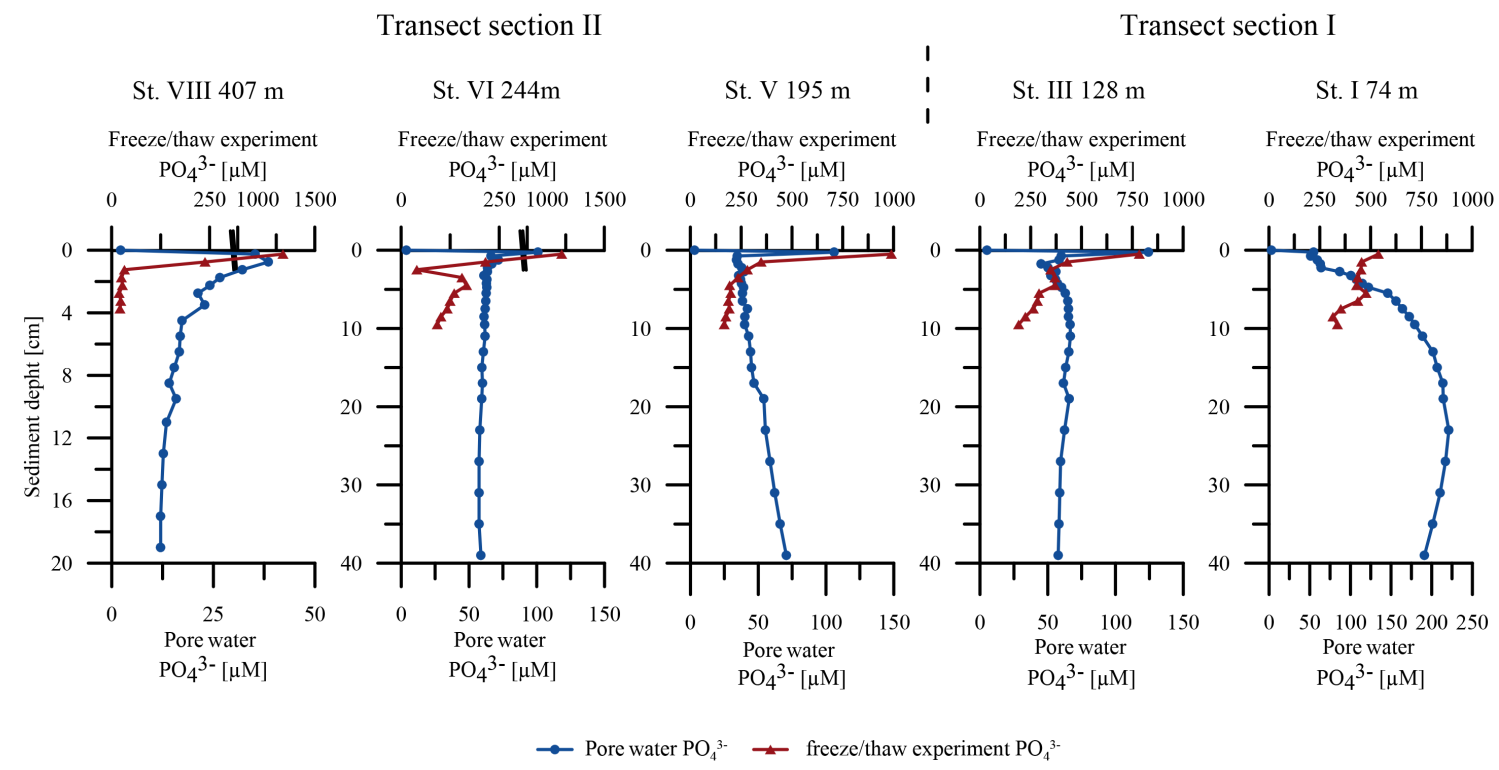

Figure 7. Comparison of porewater $\mathrm{PO}_{4}^{3-}$ concentrations before (blue) and after the freeze-thaw experiments (red) in $\mu \mathrm{mol} \mathrm{L}^{-1}$.

2009a). These different fluxes may be at least partly explained by the methodological difference (present flux measurement vs. long-term average). However, growth rates determined on modern nodules are broadly consistent with our flux measurements (Burnett et al., 1982).

\section{Conclusions}

This study aimed to identify the $\mathrm{P}$ sources of benthic $\mathrm{P}$ release in the Peruvian OMZ. We determined the rain rates of particulate organic phosphorus and particulate inorganic phosphorus as well as benthic $\mathrm{P}$ release rates and $\mathrm{P}$ burial fluxes.

Our calculations revealed that within the core OMZ particulate phosphorus rain rates cannot account for measured benthic $\mathrm{P}$ fluxes and burial fluxes. From systematic analysis of potential $\mathrm{P}$ sources, we conclude that periodic $\mathrm{P}$ release from sulfur bacteria that store and release $\mathrm{P}$ under oscillation redox conditions could strongly modulate benthic $\mathrm{P}$ fluxes, and hence explain the missing $\mathrm{P}$ source. We visited the area during austral summer when oxygen and nitrate levels were depleted by high export production and respiration. It is possible that the Peruvian OMZ was less reducing prior to our sampling period due to lower respiration rates and/or better ventilation. Thus, we propose that the bacterial mats on the Peruvian margin act as phosphorus capacitors, being discharged during austral summer and recharged during other periods of the year when bottom waters are less reducing, as previously proposed in Dale et al. (2013). This hypothesis could be tested by studying the seasonality of benthic fluxes in the Peruvian upwelling system and $\mathrm{P}$ dynamics within the bacterial community.
In addition, measurements at one station (407 $\mathrm{m}$ water depth) showed clear indications for the uptake of dissolved phosphate by the sediments facilitating phosphorite formation. Our data imply that most of the $\mathrm{P}$ accumulating in these authigenic minerals originates from ambient bottom waters. Since this site was marked by a high abundance of benthic foraminifera, we speculate that phosphate uptake and phosphorite formation may be linked to the presence of these organisms. This requires further study.

There was no clear preferential mineralization of POP relative to POC with depth in the water column. POC / TPP ratios in both water-column particles and sediments were close to Redfield at most sites in the Peruvian OMZ. This observation strongly suggests that the relative burial efficiencies of POC and TPP are similar under low-oxygen conditions. Importantly, it further shows that the sediments underlying the anoxic waters on the Peru margin are not depleted in $\mathrm{P}$ compared to Redfield. Rather, they are depleted relative to sediments underlying oxic waters, which show POC / TPP ratios well below Redfield (Wallmann, 2010). Thus, in Peru, a lack of oxygen promotes the intensified release of dissolved $\mathrm{P}$ from sediments, whilst preserving a POC / TPP burial ratio that is similar to Redfield.

Our data support the hypothesis that benthic P release is linked via a positive feedback loop to intensified primary production in the surface water and oxygen demand in the water column during periods where bottom water redox conditions promote the release of $\mathrm{P}$ from the sediments. However, this positive feedback is limited by the formation of authigenic inorganic $\mathrm{P}$ phases that maintains the long-term average POC / TPP burial ratio close to Redfield. 


\section{The Supplement related to this article is available online at doi:10.5194/bg-13-1367-2016-supplement.}

Author contributions. U. Lomnitz, A. W. Dale, and S. Sommer supported the shipboard work and geochemical analysis, and contributed to the manuscript. C. Hensen, K. Wallmann, and A. Noffke helped with fruitful discussions related to the manuscript and helped with the manuscript preparation. C. R. Löscher carried out the molecular analysis and contributed to the manuscript.

Acknowledgements. We are very grateful to the crew of RV Meteor during cruise M92 for the support. Our thanks also go to A. Petersen, M. Türk, and S. Cherednichenko for their assistance in deploying the landers. For their enthusiastic help and cooperation, we thank B. Domeyer, S. Kriwanek, A. Bleyer, R. Suhrberg, S. Trinkler, and V. Thoenissen for biogeochemical analyses on board and in the home laboratory. Furthermore, we appreciate Christopher Voigt from the University of Bremen for carrying out XRD analysis. This work is a contribution of the Sonderforschungsbereich 754 "Climate - Biogeochemistry Interactions in the Tropical Ocean" (www.sfb754.de), which is supported by the Deutsche Forschungsgemeinschaft.

Edited by: J. Middelburg

\section{References}

Anderson, L. D., Delaney, M. L., and Faul, K. L.: Carbon to phosphorus ratios in sediments: Implications for nutrient cycling, Global Biogeochem. Cy., 15, 65-79, 2001.

Arning, E. T., Birgel, D., Schulz-Vogt, H. N., Holmkvist, L., Jørgensen, B. B., Larson, A., and Peckmann, J.: Lipid Biomarker Patterns of Phosphogenic Sediments from Upwelling Regions, Geomicrobiol. J., 25, 69-82, 2008.

Arning, E. T., Birgel, D., Brunner, B., and Peckmann, J.: Bacterial formation of phosphatic laminites off Peru, Geobiology, 7, 295307, 2009a.

Arning, E. T., Lückge, A., Breuer, C., Gussone, N., Birgel, D., and Peckmann, J.: Genesis of phosphorite crusts off Peru, Mar. Geol., 262, 68-81, 2009b.

Asahi, T., Ichimi, K., Yamaguchi, H., and Tada, K.: Horizontal distribution of particulate matter and its characterization using phosphorus as an indicator in surface coastal water, Harima-Nada, the Seto Inland Sea, Japan, J. Oceanogr., 70, 277-287, 2014.

Aspila, K. I., Agemian, H., and Chau, A. S. Y.: A semi-automated Method for the Determination of Inorganic, Organic and Total Phosphate in Sediments, Analyst, 101, 187-197, 1976.

Baturin, G. N.: Issue of the relationship between primary productivity of organic carbon in ocean and phosphate accumulation (Holocene-Late Jurassic), Lithol. Miner. Resour., 42, 318-348, doi:10.1134/S0024490207040025, 2007.

Benitez-Nelson, C. R.: The biogeochemical cycling of phosphorus in marine systems, Earth-Sci. Rev., 51, 109-135, 2000.
Benitez-Nelson, C. R., O’Neill, L., Kolowith, L. C., Pellechia, P., and Thunell, R.: Phosphonates and particulate organic phosphorus cycling in an anoxic marine basin, Limnol. Ocean., 49, 15931604, 2004.

Benitez-Nelson, C. R., O’Neill Madden, L. P., Styles, R. M., Thunell, R. C., and Astor, Y.: Inorganic and organic sinking particulate phosphorus fluxes across the oxic/anoxic water column of Cariaco Basin, Venezuela, Mar. Chem., 105, 90-100, 2007.

Bertics, V. J., Löscher, C. R., Salonen, I., Dale, A. W., Gier, J., Schmitz, R. A., and Treude, T.: Occurrence of benthic microbial nitrogen fixation coupled to sulfate reduction in the seasonally hypoxic Eckernförde Bay, Baltic Sea, Biogeosciences, 10, 1243-1258, doi:10.5194/bg-10-1243-2013, 2013.

Boudreau, B. P.: The diffusive tortuosity of fine-grained unlithified sediments, Geochim. Cosmochim. Ac., 60, 3139-3142, 1996.

Brock, J. and Schulz-Vogt, H. N.: Sulfide induces phosphate release from polyphosphate in cultures of a marine Beggiatoa strain, ISME J., 5, 497-506, 2011.

Burnett, W. C., Beers, M. J., and Roe, K. K.: Growth Rates of Phosphate Nodules from the Continental Margin Off Peru, Science, 215, 1616-1618, 1982.

Colman, A. S., Mackenzie, F. T., and Holland, H. D.: Redox Stabilization of the Atmosphere and Oceans and Marine Productivity, Science, 275, 406-408, 1997.

Compton, J., Mallinson, D., Glenn, C., Filippelli, G., Föllmi, K., Shields, G., and Zanin, Y.: Variations in the global phosphorus cycle, in Marine authigenesis: from global to microbial, SEPM (Society for Sedimentary Geology), Special Publication No. 66, 21-33, 2000.

Cosmidis, J., Benzerara, K., Menguy, N., and Arning, E.: Microscopy evidence of bacterial microfossils in phosphorite crusts of the Peruvian shelf: Implications for phosphogenesis mechanisms, Chem. Geol., 359, 10-22, 2013.

Dale, A. W., Bertics, V. J., Treude, T., Sommer, S., and Wallmann, K.: Modeling benthic-pelagic nutrient exchange processes and porewater distributions in a seasonally hypoxic sediment: evidence for massive phosphate release by Beggiatoa?, Biogeosciences, 10, 629-651, doi:10.5194/bg-10-629-2013, 2013.

Dale, A. W., Sommer, S., Lomnitz, U., Montes, I., Treude, T., Liebetrau, V., Gier, J., Hensen, C., Dengler, M., Stolpovsky, K., Bryant, L. D., and Wallmann, K.: Organic carbon production, mineralisation and preservation on the Peruvian margin, Biogeosciences, 12, 1537-1559, doi:10.5194/bg-12-1537-2015, 2015.

de Jager, H.-J. and Heyns, A. M.: Kinetics of Acid-Catalyzed Hydrolysis of a Polyphosphate in Water, J. Phys. Chem. A, 102, 2838-2841, 1998.

Delaney, M. L.: Phosphorus accumulation in marine sediments and the oceanic phosphorus cycle, Global Biogeochem. Cy., 12, 563$572,1998$.

Díaz-Ochoa, J. A., Lange, C. B., Pantoja, S., De Lange, G. J., Gutierrez, D., Munoz, P., and Salamanca, M.: Fish scales in sediments from off Callao, central Peru, Deep-Sea Res. Pt. II, 56, 1113-1124, 2009.

Faul, K. L., Paytan, A., and Delaney, M. L.: Phosphorus distribution in sinking oceanic particulate matter, Mar. Chem., 97, 307-333, 2005.

Filippelli, G. M.: The global phosphorus cycle, in Phosphates: Geochemical, Geobiological, and Materials Importance, edited by: 
Kohn, M., Rakovan, J., and Hughes, J., Reviews in Mineralogy \& Geochemistry, 391-425, 2002.

Filippelli, G. M.: The Global Phosphorus Cycle: Past, Present, and Future, Elements, 4, 89-95, 2008.

Föllmi, K. B.: The phosphorus cycle, phosphogenesis and marine phosphate-rich deposits, Earth-Sci. Rev., 40, 55-124, 1996.

Franz, J., Krahmann, G., Lavik, G., Grasse, P., Dittmar, T., and Riebesell, U.: Dynamics and stoichiometry of nutrients and phytoplankton in waters influenced by the oxygen minimum zone in the eastern tropical Pacific, Deep-Sea Res. Pt. I, 62, 20-31, 2012.

Froelich, P. N., Arthur, M. A., Burnett, W. C., Deakin, M., Hensley, V., Jahnke, R., Kaul, L., Kim, K. H., Roe, K., Soutar, A., and Vathakanon, C.: Early diagenesis of organic matter in Peru continental margin sediments: Phosphorite precipitation, Mar. Geol., 80, 309-343, 1988.

Fuenzalida, R., Schneider, W., Garcés-Vargas, J., Bravo, L., and Lange, C.: Vertical and horizontal extension of the oxygen minimum zone in the eastern South Pacific Ocean, Deep-Sea Res. Pt. II, 56, 992-1003, 2009.

Ganeshram, R. S., Pedersen, T. F., Calvert, S., and Francois, R.: Reduced nitrogen fixation in the glacial ocean inferred from changes in marine nitrogen and phosphorus inventories, Nature, 415, 156-159, 2002.

Glenn, C. R. and Arthur, M. A.: Petrology and major element geochemistry of Peru margin phosphorites and associated diagenetic minerals: Authigenesis in modern organic-rich sediments, Mar. Geol., 80, 231-267, 1988.

Goldhammer, T., Bruchert, V., Ferdelman, T. G., and Zabel, M.: Microbial sequestration of phosphorus in anoxic upwelling sediments, Nat. Geosci., 3, 557-561, 2010.

Govindaraju, K.: Compilation of working values and sample description for 383 geostandards, Geostandard Newslett., 18, 1158, 1994.

Graco, M., Purca, S., Dewitte, B., Morón, O., Ledesma, J., Flores, G., Castro, C., and Gutiérrez, D.: The OMZ and nutrients features as a signature of interannual and low frequency variability off the peruvian upwelling system, Biogeosciences Discuss., doi:10.5194/bg-2015-567, in review, 2016.

Grasshoff, K., Erhardt, M., and Kremling, K.: Methods of seawater analysis, 3rd Edn., Wiley-VCH, Weinheim, New York, Chiester, Brisbane, Singapore, Toronto, 1999.

Gutiérrez, D., Enríquez, E., Purca, S., Quipúzcoa, L., Marquina, R., Flores, G., and Graco, M.: Oxygenation episodes on the continental shelf of central Peru: Remote forcing and benthic ecosystem response, Prog. Oceanogr., 79, 177-189, 2008.

Hedges, J. I., Hu, F. S., Devol, A. H., Hartnett, H. E., Tsamakis, E., and Keil, R. G.: Sedimentary organic matter preservation: A test for selective degradation under oxic conditions, Am. J. Sci., 299, 529-555, 1999.

Høgslund, S., Revsbech, N. P., Kuenen, J. G., Jorgensen, B. B., Gallardo, V. A., Vossenberg, J. V. D., Nielsen, J. L., Holmkvist, L., Arning, E. T., and Nielsen, L. P.: Physiology and behaviour of marine Thioploca, ISME J., 3, 647-657, 2009.

Holmkvist, L., Arning, E. T., Küster-Heins, K., Vandieken, V., Peckmann, J., Zabel, M., and Jørgensen, B. B.: Phosphate geochemistry, mineralization processes, and Thioploca distribution in shelf sediments off central Chile, Mar. Geol., 277, 61-72, 2010 .
Ingall, E. and Jahnke, R.: Evidence for enhanced phosphorus regeneration from marine sediments overlain by oxygen depleted waters, Geochim. Cosmoch. Ac., 58, 2571-2575, 1994.

Ingall, E. and Jahnke, R.: Influence of water-column anoxia on the elemental fractionation of carbon and phosphorus during sediment diagenesis, Mar. Geol., 139, 219-229, 1997.

Ingall, E., Kolowith, L., Lyons, T., and Hurtgen, M.: Sediment carbon, nitrogen and phosphorus cycling in an anoxic fjord, Effingham Inlet, British Columbia, Am. J. Sci., 305, 240-258, 2005.

Ingall, E. D.: Biogeochemistry: Phosphorus burial, Nat. Geosci., 3, 521-522, 2010.

Ingall, E. D. and Van Cappellen, P.: Relation between sedimentation rate and burial of organic phosphorus and organic carbon in marine sediments, Geochim. Cosmochim. Ac., 54, 373-386, 1990.

Jahnke, R. A.: Early diagenesis and recycling of biogenic debris at the seafloor, Santa Monica Basin, California, J. Mar. Res., 48, 413-436, 1990.

Jilbert, T., Slomp, C. P., Gustafsson, B. G., and Boer, W.: Beyond the Fe-P-redox connection: preferential regeneration of phosphorus from organic matter as a key control on Baltic Sea nutrient cycles, Biogeosciences, 8, 1699-1720, doi:10.5194/bg-8-16992011, 2011.

Kraal, P., Slomp, C. P., Reed, D. C., Reichart, G.-J., and Poulton, S. W.: Sedimentary phosphorus and iron cycling in and below the oxygen minimum zone of the northern Arabian Sea, Biogeosciences, 9, 2603-2624, doi:10.5194/bg-9-2603-2012, 2012.

Kraal, P., Bostick, B. C., Behrends, T., Reichart, G.-J., and Slomp, C. P.: Characterization of phosphorus species in sediments from the Arabian Sea oxygen minimum zone: Combining sequential extractions and X-ray spectroscopy, Mar. Chem., 168, 1-8, 2015.

Krissek, L. A., Scheidegger, K. F., and Kulm, L. D.: Surface sediments of the Peru-Chile continental margin and the Nazca plate, Geol. Soc. Am. Bull., 91, 321-331, 1980.

Labry, C., Youenou, A., Delmas, D., and Michelon, P.: Addressing the measurement of particulate organic and inorganic phosphorus in estuarine and coastal waters, Cont. Shelf Res., 60, 28-37, 2013.

Li, Y.-H. and Gregory, S.: Diffusion of ions in sea water andin deepsea sediments, Geochim. Cosmochim. Ac., 38, 703-714, 1974.

Loh, A. N. and Bauer, J. E.: Distribution, partitioning and fluxes of dissolved and particulate organic C, N and P in the eastern North Pacific and Southern Oceans, Deep-Sea Res. Pt. I, 47, 22872316, 2000.

Löscher, C. R., Kock, A., Könneke, M., LaRoche, J., Bange, H. W., and Schmitz, R. A.: Production of oceanic nitrous oxide by ammonia-oxidizing archaea, Biogeosciences, 9, 2419-2429, doi:10.5194/bg-9-2419-2012, 2012.

Lyons, G., Benitez-Nelson, C. R., and Thunell, R. C.: Phosphorus composition of sinking particles in the Guaymas Basin, Gulf of California, Limnol. Oceanogr., 56, 1093-1105, 2011.

McManus, J., Berelson, W. M., Coale, K. H., Johnson, K. S., and Kilgore, T. E.: Phosphorus regeneration in continental margin sediments, Geochim. Cosmochim. Ac., 61, 2891-2907, 1997.

Moffitt, S. E., Moffitt, R. A., Sauthoff, W., Davis, C. V., Hewett, K., and Hill, T. M.: Paleoceanographic Insights on Recent Oxygen Minimum Zone Expansion: Lessons for Modern Oceanography, PLoS ONE, 10, doi:10.1371/journal.pone.0115246, 2015. 
Mort, H. P., Slomp, C. P., Gustafsson, B. G., and Andersen, T. J.: Phosphorus recycling and burial in Baltic Sea sediments with contrasting redox conditions, Geochim. Cosmochim. Ac., 74, 1350-1362, 2010.

Mosch, T., Sommer, S., Dengler, M., Noffke, A., Bohlen, L., Pfannkuche, O., Liebetrau, V., and Wallmann, K.: Factors influencing the distribution of epibenthic megafauna across the Peruvian oxygen minimum zone, Deep-Sea Res. Pt. I, 68, 123-135, 2012.

Noffke, A.: Phosphorus cycling in anoxic sediments, PhD dissertation, University of Kiel, Kiel, 2014.

Noffke, A., Hensen, C., Sommer, S., Scholz, F., Bohlen L., Mosch, T., Graco, M., and Wallmann, K.: Benthic iron and phosphorus fluxes across the Peruvian oxygen minimum zone, Limnol. Oceanogr., 57, 851-867, 2012.

Noffke, A., Sommer, S., Dale, A. W., Hall, P. O. J., and Pfannkuche, O.: Benthic nutrient fluxes in the Eastern Gotland Basin (Baltic Sea) with particular focus on microbial mat ecosystems, J. Marine Syst., 158, 1-12, doi:10.1016/j.jmarsys.2016.01.007, 2016.

Paytan, A. and McLaughlin, K.: The Oceanic Phosphorus Cycle, Chem. Rev., 107, 563-576, 2007.

Paytan, A., Cade-Menun, B. J., McLaughlin, K., and Faul, K. L.: Selective phosphorus regeneration of sinking marine particles: evidence from 31P-NMR, Mar. Chem., 82, 55-70, 2003.

Pennington, J. T., Mahoney, K. L., Kuwahara, V. S., Kolber, D. D., Calienes, R., and Chavez, F. P.: Primary production in the eastern tropical Pacific: A review, Prog. Oceanogr., 69, 285-317, 2006.

Redfield, A. C., Ketchum, B. H., and Richards, F. A.: The influence of organisms on the composition of seawater, in: The Sea, Academic Press, London, 26-77, 1963.

Reimers, C. E. and Suess, E.: Spatial and temporal patterns of organic matter accumulation on the Peru continental margin, in: Coastal Upwelling: Part B, Sedimentary Record of Ancient Coastal Upwelling, edited by: Suess, E. and Thiede, J., Plenum Press, New York, 311-346, 1983.

Roth, R., Ritz, S. P., and Joos, F.: Burial-nutrient feedbacks amplify the sensitivity of atmospheric carbon dioxide to changes in organic matter remineralisation, Earth Syst. Dynam., 5, 321-343, doi:10.5194/esd-5-321-2014, 2014.

Ruttenberg, K. C.: The Global Phosphorus Cycle, in: Treatise on Geochemistry, edited by: Turekian, K. K. and Holland, D. J., Elsevier, Oxford, 585-643, 2003.

Ruttenberg, K. C.: The Global Phosphorus Cycle, in: Treatise on Geochemistry, edited by: Holland, H. D. and Turekian, K. K., Elsevier, Oxford, 499-558, 2014.

Ruttenberg, K. C. and Berner, R. A.: Authigenic apatite formation and burial in sediments from non-upwelling, continental margin environments, Geochim. Cosmochim. Ac., 57, 991-1007, 1993.

Salman, V., Amann, R., Girnth, A.-C., Polerecky, L., Bailey, J. V., Høgslund, S., Jessen, G., Pantoja, S., and Schulz-Vogt, H. N.: A single-cell sequencing approach to the classification of large, vacuolated sulfur bacteria, Syst. Appl. Microbiol., 34, 243-259, 2011

Salman, V., Amann, R, Shub, D. A., and Schulz-Vogt, H. N.: Multiple self-splicing introns in the 16S rRNA genes of giant sulfur bacteria, P. Natl. Acad. Sci. USA, 109, 4203-4208, doi:10.1073/pnas.1120192109, 2012.
Sannigrahi, P. and Ingall, E.: Polyphosphates as a source of enhanced $P$ fluxes in marine sediments overlain by anoxic waters: Evidence from 31P NMR, Geochem. T., 6, 52-59, 2005.

Sanudo-Wilhelmy, S. A., Tovar-Sanchez, A., Fu, F.-X., Capone, D. G., Carpenter, E. J., and Hutchins, D. A.: The impact of surfaceadsorbed phosphorus on phytoplankton Redfield stoichiometry, Nature, 432, 897-901, 2004

Schenau, S. J. and De Lange, G. J.: A novel chemical method to quantify fish debris in marine sediments, Limnol. Oceanogr., 45, 963-971, 2000.

Schenau, S. J. and De Lange, G. J.: Phosphorus regeneration vs. burial in sediments of the Arabian Sea, Mar. Chem., 75, 201217, 2001.

Scholz, F., Hensen, C., Noffke, A., Rohde, A., Liebetrau, V., and Wallmann, K.: Early diagenesis of redox-sensitive trace metals in the Peru upwelling area - response to ENSO-related oxygen fluctuations in the water column, Geochim. Cosmochim. Ac., 75, 7257-7276, 2011.

Schulz, H. N. and Jørgensen, B. B.: Thiomargarita, in: Bergey's Manual of Determinative Bacteriology, edited by: Krieg, N. R., Staley, J. T., and Brenner, D. J., Vol. 2, part B, Springer-Verlag, Berlin, Heidelberg, New York, 2005.

Schulz, H. N. and Schulz, H. D.: Large Sulfur Bacteria and the Formation of Phosphorite, Science, 307, 416-418, 2005.

Schunck, H., Lavik, G., Desai, D. K., Großkopf, T., Kalvelage, T., Löscher, C. R., Paulmier, A., Contreras, S., Siegel, H., Holtappels, M., Rosenstiel, P., Schilhabel, M. B., Graco, M., Schmitz, R. A., Kuypers, M. M. M., and LaRoche, J.: Giant Hydrogen Sulfide Plume in the Oxygen Minimum Zone off Peru Supports Chemolithoautotrophy, PLoS ONE, 8, doi:10.1371/journal.pone.0068661, 2013.

Sekula-Wood, E., Benitez-Nelson, C. R., Bennett, M. A., and Thunell, R.: Magnitude and composition of sinking particulate phosphorus fluxes in Santa Barbara Basin, California, Global Biogeochem. Cy., 26, GB2023, doi:10.1029/2011GB004180, 2012.

Slomp, C. P. and Van Cappellen, P.: The global marine phosphorus cycle: sensitivity to oceanic circulation, Biogeosciences, 4, 155171, doi:10.5194/bg-4-155-2007, 2007.

Slomp, C. P., Van der Gaast, S. J., and Van Raaphorst, W.: Phosphorus binding by poorly crystalline iron oxides in North Sea sediments, Mar. Chem., 52, 55-73, 1996.

Slomp, C. P., Malschaert, J. F. P., and Van Raaphorst, W.: The role of adsorption in sediment-water exchange of phosphate in North Sea continental margin sediments, Limnol. Oceanogr., 43, 832846, 1998.

Sommer, S., Linke, P., Pfannkuche, O., Schleicher, T., Schneider v. Deimling, J., Reitz, A., Haeckel, M., and Hensen, C.: Seabed methane emissions and the habitat of frenulate tubeworms on the Captain Arutyunov mud volcano (Gulf of Cadiz), Mar. Ecol.Prog. Ser., 382, 69-86, 2009.

Sommer, S., Gier, J., Treude, T., Lomnitz, U., Dengler, M., Cardich, J., and Dale, A.: Depletion of oxygen, nitrate and nitrite in the Peruvian oxygen minimum zone cause an imbalance of benthic nitrogen fluxes, Deep-Sea Res. Pt. I, accepted, 2016.

Stramma, L., Johnson, G. C., Sprintall, J., and Mohrholz, V.: Expanding Oxygen-Minimum Zones in the Tropical Oceans, Science, 320, 655-658, 2008. 
Strub, P. T., Mesias, J. M., Montecino, V., Ontecino, R., and Salinas, S.: Coastal ocean circulation of western South. America, in: The Sea, edited by: Robinson, A. R. and Brink, K. H., Wiley, New York, 273-313, 1998.

Suess, E.: Phosphate regeneration from sediments of the Peru continental margin by dissolution of fish debris, Geochim. Cosmochim. Ac., 45, 577-588, 1981.

Suess, E. and von Huene, R.: Ocean Drilling Program Leg 112, Peru continental margin: Part 2, Sedimentary history and diagenesis in a coastal upwelling environment, Geology, 16, 939-943, 1988.

Suess, E., Kulm, L. D., and Killingley, J. S.: Coastal upwelling and a history of organic rich mudstone deposition off Peru, in: Marine Petroleum Source rocks, edited by: Brooks, J. and Fleet, A. J., Geological Society Spec, 1129-1145, 1987.

Sundby, B., Anderson, L. G., Hall, P. O. J., Iverfeldt, Å., van der Loeff, M. M. R., and Westerlund, S. F. G.: The effect of oxygen on release and uptake of cobalt, manganese, iron and phosphate at the sediment-water interface, Geochim. Cosmochim. Ac., 50, 1281-1288, 1986.

Tamura, K., Stecher, G., Peterson, D., Filipski, A., and Kumar, S.: MEGA6, Molecular Evolutionary Genetics Analysis Version 6.0., Mol. Biol. Evol., 30, 2725-2729, 2013.
Teske, A., Ramsing, N. B., Küver, J., and Fossing, H.: Phylogeny of Thioploca and Related Filamentous Sulfide-Oxidizing Bacteria, Syst. Appl. Microbiol., 18, 517-526, 1995.

Tsandev, I., Reed, D. C., and Slomp, C. P.: Phosphorus diagenesis in deep-sea sediments: Sensitivity to water column conditions and global scale implications, Chem. Geol., 330-331, 127-139, 2012.

Van Cappellen, P. and Ingall, E. D.: Redox Stabilization of the Atmosphere and Oceans by Phosphorus-Limited Marine Productivity, Science, 271, 493-496, 1996.

Viers, J., Dupré, B., and Gaillardet, J.: Chemical composition of suspended sediments in World Rivers: New insights from a new database, Sci. Total Environ., 407, 853-868, 2009.

Wallmann, K.: Feedbacks between oceanic redox states and marine productivity: A model perspective focused on benthic phosphorus cycling, Global Biogeochem. Cy., 17, doi:10.1029/2002GB001968, 2003.

Wallmann, K.: Phosphorus imbalance in the global ocean?, Global Biogeochem. Cy., 24, doi:10.1029/2009GB003643, 2010. 